\title{
Effects of High-Octane E25 on Two Vehicles Equipped with Turbocharged, Direct-Injection Engines
}

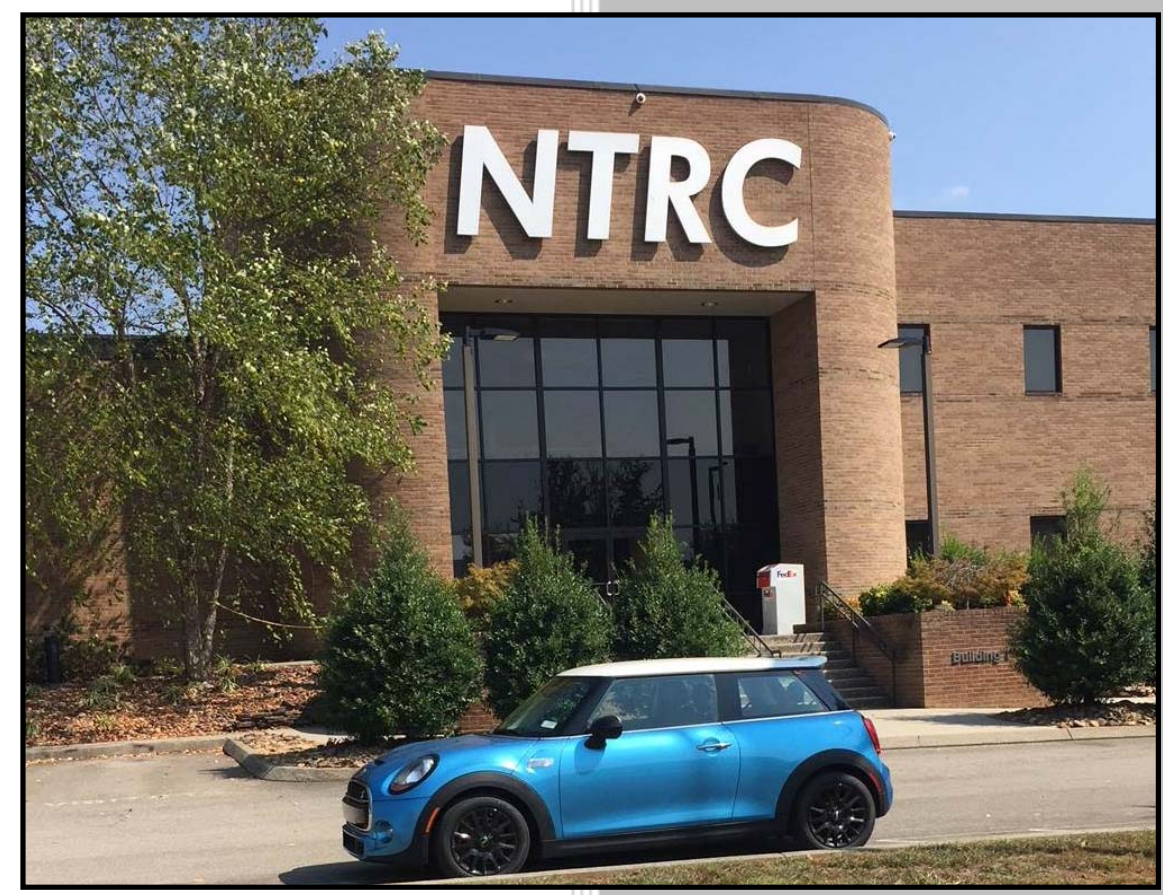

Approved for public release.

Distribution is unlimited

Brian West

Shean Huff

Larry Moore Melanie DeBusk

Scott Sluder

September 2018 


\title{
DOCUMENT AVAILABILITY
}

Reports produced after January 1, 1996, are generally available free via US Department of Energy (DOE) SciTech Connect.

Website www.osti.gov

Reports produced before January 1, 1996, may be purchased by members of the public from the following source:

\author{
National Technical Information Service \\ 5285 Port Royal Road \\ Springfield, VA 22161 \\ Telephone 703-605-6000 (1-800-553-6847) \\ TDD 703-487-4639 \\ Fax 703-605-6900 \\ E-mail info@ntis.gov \\ Website http://classic.ntis.gov/
}

Reports are available to DOE employees, DOE contractors, Energy Technology Data Exchange representatives, and International Nuclear Information System representatives from the following source:

Office of Scientific and Technical Information

PO Box 62

Oak Ridge, TN 37831

Telephone 865-576-8401

Fax 865-576-5728

E-mail reports@osti.gov

Website http://www.osti.gov/contact.html

This report was prepared as an account of work sponsored by an
agency of the United States Government. Neither the United States
Government nor any agency thereof, nor any of their employees, makes
any warranty, express or implied, or assumes any legal liability or
responsibility for the accuracy, completeness, or usefulness of any
information, apparatus, product, or process disclosed, or represents that
its use would not infringe privately owned rights. Reference herein to
any specific commercial product, process, or service by trade name,
trademark, manufacturer, or otherwise, does not necessarily constitute
or imply its endorsement, recommendation, or favoring by the United
States Government or any agency thereof. The views and opinions of
authors expressed herein do not necessarily state or reflect those of the
United States Government or any agency thereof. 
National Transportation Research Center

\title{
EFFECTS OF HIGH-OCTANE E25 ON TWO VEHICLES EQUIPPED WITH TURBOCHARGED, DIRECT-INJECTION ENGINES
}

\author{
Brian West \\ Shean Huff \\ Larry Moore \\ Melanie DeBusk \\ Scott Sluder
}

Date Published: September 2018

\author{
Prepared by \\ OAK RIDGE NATIONAL LABORATORY (ORNL) \\ Oak Ridge, TN 37831-6283 \\ managed by \\ UT-BATTELLE, LLC \\ for the \\ US DEPARTMENT OF ENERGY \\ under contract DE-AC05-00OR22725
}





\section{CONTENTS}

Page

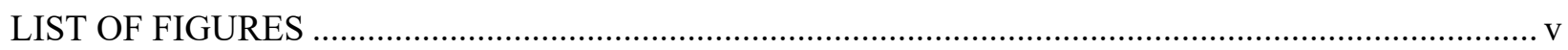

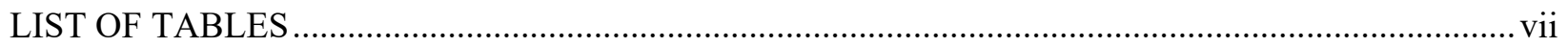

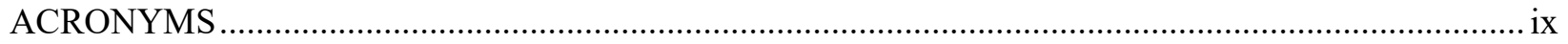

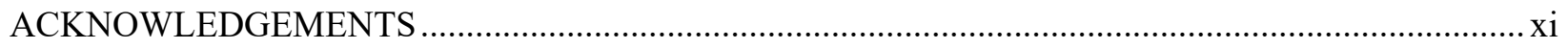

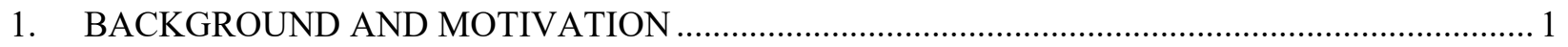

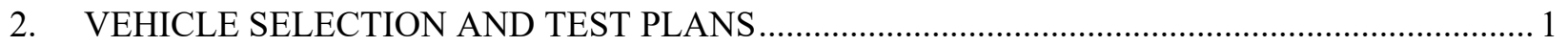

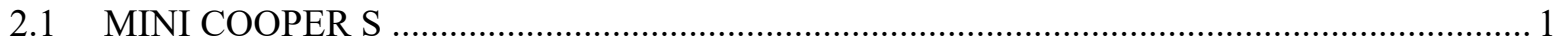

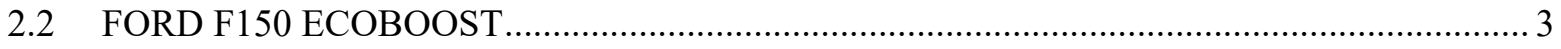

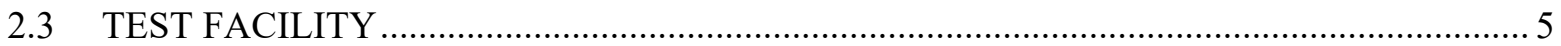

3. TEST FUELS AND GASOLINE EQUIVALENT FUEL ECONOMY …................................ 7

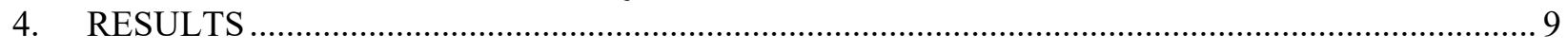

4.1 MINI COOPER FUEL ECONOMY/EFFICIENCY …................................................. 9

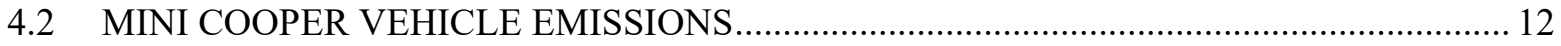

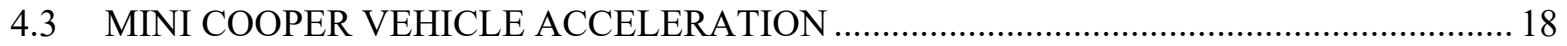

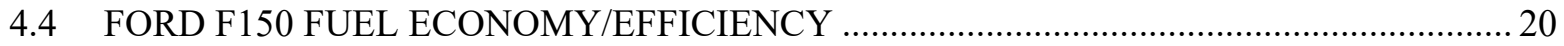

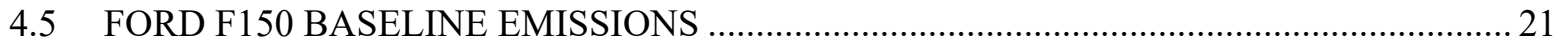

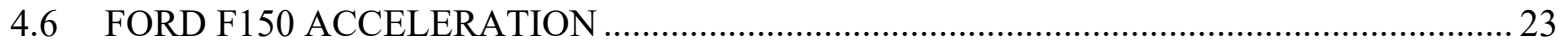

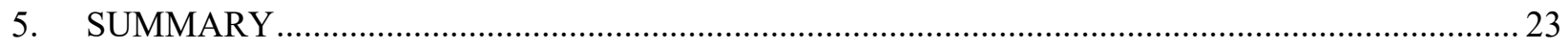

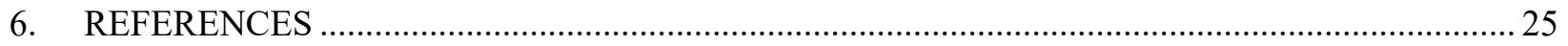





\section{LIST OF FIGURES}

Figure 1. 2015 MINI Cooper S in the ORNL Vehicle Laboratory..................................................... 2

Figure 2. Road Load Horsepower for 2015 MINI Cooper S and 2006 Dodge Charger........................... 3

Figure 3. 2016 Ford F150 in the ORNL Vehicle Laboratory. ........................................................... 4

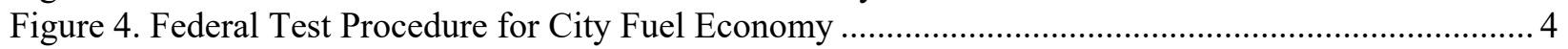

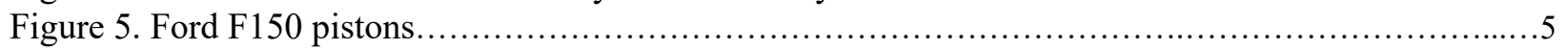

Figure 6. FTP Fuel Economy for MINI Cooper S at two test weights, with two fuels, and two shift schedules.

Figure 7. Highway Fuel Economy Test Results for MINI Cooper S at two test weights, with two fuels and two shift schedules.

Figure 8. US06 Fuel Economy for MINI Cooper S at two test weights with two fuels.

Figure 9. FTP NMOG emissions for 2015 MINI Cooper at two test weights, with two fuels and two shift schedules.

Figure 10. FTP NOx emissions for 2015 MINI Cooper at two test weights, with two fuels and two shift schedules.

Figure 11. FTP NMOG + NOx emissions for 2015 MINI Cooper at two test weights, with two fuels and two shift schedules.

Figure 12. FTP CO emissions for 2015 MINI Cooper at two test weights, with two fuels and two shift schedules.

Figure 13. US06 NMOG emissions for 2015 MINI Cooper at two test weights with two fuels............... 16

Figure 14. US06 NOx emissions for 2015 MINI Cooper at two test weights with two fuels.................... 17

Figure 15. US06 NMOG + NOx emissions for MINI Cooper at two test weights with two fuels............ 17

Figure 16. US06 CO emissions for MINI Cooper at two test weights with two fuels............................. 18

Figure 17. Minimum wide-open-throttle acceleration times for MINI Cooper with E10 and E25 at

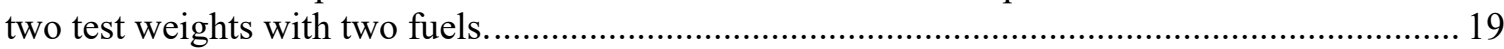

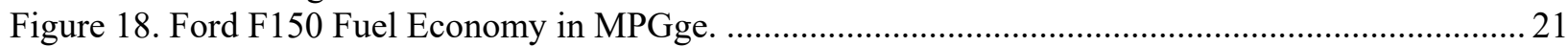

Figure 19. Cold LA4 particulate emissions for Ford F150 with two fuels. .............................................. 22 


\section{LIST OF TABLES}

Table 1. EPA Shift Schedule and ORNL downspeed schedule for MINI Cooper................................... 3

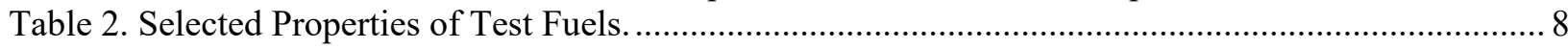

Table 3. Average fuel economy in MPGge for MINI Cooper S experiments at two test weights with two fuels with two shift schedules...................................................................................... 9

Table 4. Average NMOG Emissions for MINI Cooper S experiments at two test weights with two fuels and two shift schedules.

Table 5. Average NOx Emissions for MINI Cooper S experiments at two test weights with two fuels and two shift schedules.

Table 6. Average NMOG+NOx Emissions for MINI Cooper S experiments at two test weights with two fuels and two shift schedules.

Table 7. Average CO Emissions for MINI Cooper S experiments at two test weights with two fuels and two shift schedules.

Table 8. MINI Cooper S 15-80 mph acceleration times at two test weights with two fuels...... 19

Table 9. Average fuel economy in MPGge for 2016 Ford F150 experiments with two fuels. 20

Table 10. FTP NOx emissions for 2016 Ford F150 experiments with two fuels in the factory condition.

Table 11. F150 15-80 mph Acceleration Time with two fuels 23 



\section{ACRONYMS}

\begin{tabular}{ll} 
AKI & anti-knock index \\
BOB & blendstock for oxygenate blending \\
CO & carbon monoxide \\
CR & compression ratio \\
DHA & detailed hydrocarbon analysis \\
DOE & U.S. Department of Energy \\
EPA & U.S. Environmental Protection Agency \\
E0 & gasoline with no ethanol content \\
E10 & gasoline with 10\% ethanol \\
E25 & gasoline with 25\% ethanol \\
ETW & equivalent test weight \\
FTP & Federal Test Procedure for the city fuel economy test \\
GHG & greenhouse gas \\
HFET & Highway Fuel Economy Test \\
HOF & high octane fuel \\
KLSA & knock limited spark advance \\
MON & motor octane number \\
MPGge & mile per gallon gasoline equivalent \\
NMOG & nonmethane organic gas \\
NOx & oxides of nitrogen \\
NTRC & National Transportation Research Center \\
OEM & original equipment manufacturer \\
ORNL & Oak Ridge National Laboratory \\
PMI & Particulate Matter Index \\
RVP & Reid vapor pressure \\
RFS & Renewable Fuel Standard \\
RON & research octane number \\
SI & spark ignition \\
SUV & sport utility vehicle \\
US06 & EPA US06 high-load, high-speed aggressive test cycle, part of the EPA Supplemental \\
I4 & Federal Test Procedure (SFTP) \\
V6 & inline 4-cylinder engine configuration \\
& V 6-cylinder engine configuration \\
& \\
\hline &
\end{tabular}





\section{ACKNOWLEDGEMENTS}

This report and the work described were sponsored by the Illinois Corn Marketing Board, the National Corn Growers Association, and the Missouri Corn Growers Association. The authors gratefully acknowledge the support and direction of David Loos, Amie Gianino, Bradley Schad, Peter Magner, Mark Palmer, and members of the Ag/Auto/Ethanol Work Group. Heartfelt thanks go to Riordan Rocha and colleagues at MAHLE Powertrain who provided the prototype pistons for the Ford engine. Thanks also to Stephen Sinkez at BMW for shift schedule information and other technical assistance associated with dynamometer testing of the MINI Cooper. This work has also benefited from input, direction, and support of related projects from numerous sponsors and peers within the DOE Vehicle Technologies Office, the Bioenergy Technologies Office, national labs, and industry. The authors acknowledge and appreciate the professional assistance of Kathy Jones with the manuscript, the many stimulating technical discussions with Jim Szybist, and the expert technical support of Steve Whitted.

The authors are indebted to many technical experts in industry and government. While these experts have provided valuable support and information as noted above, this guidance does not constitute endorsement by their organizations of either the study or the results. 



\section{BACKGROUND AND MOTIVATION}

Vehicle manufacturers are developing and introducing new technologies to improve fuel economy and reduce vehicle carbon dioxide $\left(\mathrm{CO}_{2}\right)$ emissions to comply with increasingly challenging regulations. Despite growing interest in electric vehicles, spark-ignition (SI) engines dominate the light-duty market in the U.S. and are expected to remain in wide use for decades. There is growing interest in making use of fuels with increased octane number to help improve engine efficiency through increased compression ratio, downsizing with turbocharging, and downspeeding. Regular gasoline in the U.S. is generally rated at $87 \mathrm{AKI}$ (anti-knock index), where the AKI is defined as the average of the Research Octane Number ${ }^{1}$ (RON) and the Motor Octane Number ${ }^{2}(\mathrm{MON})$. Most regular gasoline in the US contains $10 \%$ ethanol (E10); the nation consumed over 14 billion gallons of ethanol in 2017. Because ethanol has an inherently high-octane number it is commonly blended into a "sub-octane BOB" (Blendstock for Oxygenate Blending) such that the resulting E10 has a minimum of $87 \mathrm{AKI}$. While AKI is the current means of rating fuels in the U.S., most researchers agree that the RON is more meaningful for most modern SI engines. ${ }^{3,4}$

Several recent publications have shown the potential efficiency benefits of high-octane fuels in boosted, direct-injection engines ${ }^{5,6,7,8,9,10}$. Improved vehicle efficiency combined with the use of renewable feedstocks such as ethanol can provide attractive well-to-wheels greenhouse gas benefits ${ }^{11,12}$.

When $15 \%$ ethanol is blended into regular gasoline (E0), the resulting fuel typically has AKI exceeding 92 (RON greater than 97), and in a vehicle equipped with a turbocharged, direct-injection engine, this fuel provides measurable efficiency gains ${ }^{13}$. When $25 \%$ ethanol is blended into sub-octane BOB, the resulting high-octane fuel has a minimum RON of $98^{14}$. Many prior studies examining the octane-enhancing benefits of ethanol have focused on $30 \%$ ethanol blends $(E 30)^{3,5,6,7,11}$. The purpose of these studies is to demonstrate, at the vehicle level, the benefits of splash-blended E25, when the base fuel is Tier 3 E10 certification gasoline with minimum 87 AKI. While $30 \%$ ethanol provides a larger RON boost than $25 \%$, E25 is of interest due to growing E25-compatible refueling infrastructure ${ }^{15,16}$.

\section{VEHICLE SELECTION AND TEST PLANS}

This report provides results for two distinct sets of vehicle experiments using turbocharged, directinjection gasoline engines. The first is a 2015 MINI Cooper S, and the second is a 2016 Ford F150. Both vehicles were evaluated with Tier 3 E10 and a splash blend of this fuel with ethanol to produce a "Tier 3 E25." Any time the fuel was changed in either vehicle, the vehicle was thoroughly prepared to ensure adaptation to the new fuel using the same rigorous protocol developed during the Mid-Level Ethanol blends program ${ }^{17,18}$.

\subsection{MINI COOPER S}

Since model year 2014, the owner's manual for the 2.0-liter MINI Cooper S states that "fuels with a maximum ethanol content of $25 \%$ " may be used ${ }^{19}$. Figure 1 shows the 2015 MINI Cooper S acquired for this study. The vehicle is equipped with a 6-speed manual transmission, and a 4-cylinder, 2.0 liter, turbocharged direct-injection engine. The odometer reading at the beginning of this test program was approximately 18,000 miles.

The MINI Cooper S is a "premium-recommended" vehicle, per the EPA Fuel Economy Database ${ }^{20}$; as stated in the owner's manual, the manufacturer recommends 91 (or 89) AKI, but consistent with the EPA listing the manufacturer states "the engine may produce knocking sounds" if lower octane fuel is used. As 
such, performance and efficiency benefits can be realized from using higher octane fuel, but no engine damage would be incurred from the use of regular gasoline ${ }^{13,21}$.

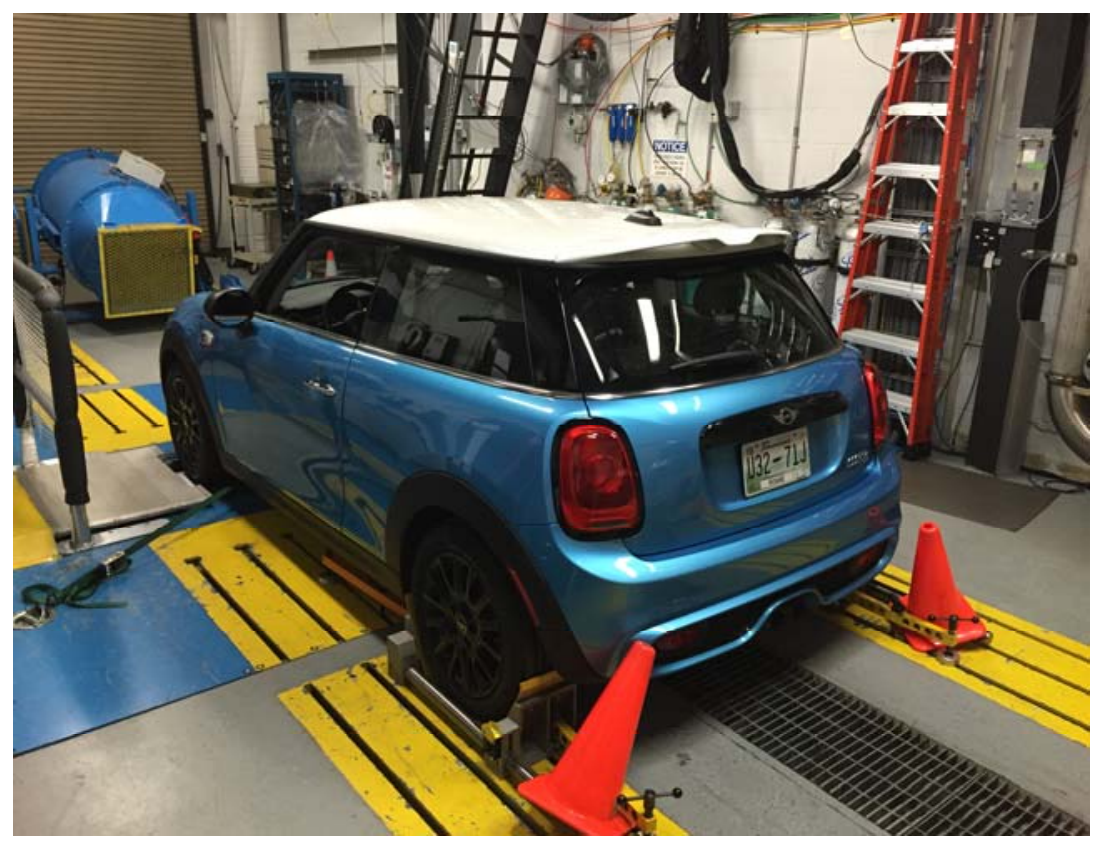

Figure 1. 2015 MINI Cooper S in the ORNL Vehicle Laboratory.

The MINI Cooper experiments included duplicate runs in the vehicle laboratory of each of the following tests: The Federal Test Procedure (FTP) or city fuel economy test, the highway fuel economy test (HFET), and the high-load, high-speed US06 ${ }^{22}$ test. ${ }^{*}$ Wide-open-throttle (WOT) tests were also run on the vehicle dynamometer to measure acceleration performance differences in the test fuels. Because the MINI Cooper was equipped with a 6-speed manual transmission, it was possible to simulate downspeeding by changing the shift schedule as shown in Table 1. Because engine friction increases with speed, adding transmission gears or changing gear ratios to reduce engine speed can enable higher fuel economy. However, at a given power output downspeeding results in higher torque demand which can promote engine knock. Knock is often mitigated via spark retard, which reduces efficiency. ${ }^{7}$ To simulate downsizing, the vehicle dynamometer coefficients and equivalent test weight (ETW) settings were changed to match those of a larger family sedan (2006 Dodge Charger). ${ }^{\dagger}$ The MINI Cooper ETW is 3125 lb., and the Charger ETW is $4500 \mathrm{lb}$. For the Charger emulation, in addition to the heaver ETW, the dynamometer coefficients also matched the road load (aerodynamic and rolling resistance) of the larger vehicle. With the heavier ETW and higher drag, the MINI Cooper would be expected to be more knockprone, thus potentially accentuating the benefits of high octane fuel. The road load horsepower (hp) for the 2015 MINI Cooper S and the 2006 Dodge Charger are shown in Figure 2. At a steady speed of 50

\footnotetext{
${ }^{*}$ The US06 is part of the Supplemental Federal Test Procedure, which also includes a controlled high-temperature, high-humidity air conditioner test.

$\dagger$ While the 2006 Charger may seem a somewhat arbitrary selection, this vehicle was evaluated in our laboratory previously and thus fuel economy and acceleration data are available for a future publication on downsizing and powertrain efficiency. The power, engine displacement, and vehicle weight are in the range of a number of vehicles available today (https://www.epa.gov/compliance-and-fuel-economy-data/data-cars-used-testing-fuel-economy).
} 
$\mathrm{mph}$, the MINI Cooper requires $8.6 \mathrm{hp}$ at the wheels to overcome the aerodynamic and rolling resistance; at the same condition the Dodge Charger requires $12.2 \mathrm{hp}$.

All experiments with the MINI Cooper were conducted in the original equipment manufacturer (OEM) condition (except for one set of acceleration tests, described later).

Table 1. EPA Shift Schedule and ORNL downspeed schedule for MINI Cooper.

\begin{tabular}{ccc}
\hline Gear Change & EPA Schedule (mph) & ORNL Downspeed Schedule (mph) \\
\hline $\mathbf{1} \rightarrow \mathbf{2}$ & 15 & 12 \\
\hline $\mathbf{2} \rightarrow \mathbf{3}$ & 25 & 20 \\
\hline $\mathbf{3} \rightarrow \mathbf{4}$ & 40 & 32 \\
\hline $\mathbf{4} \rightarrow \mathbf{5}$ & 45 & 36 \\
\hline $\mathbf{5} \rightarrow \mathbf{6}$ & 50 & 40 \\
\hline
\end{tabular}

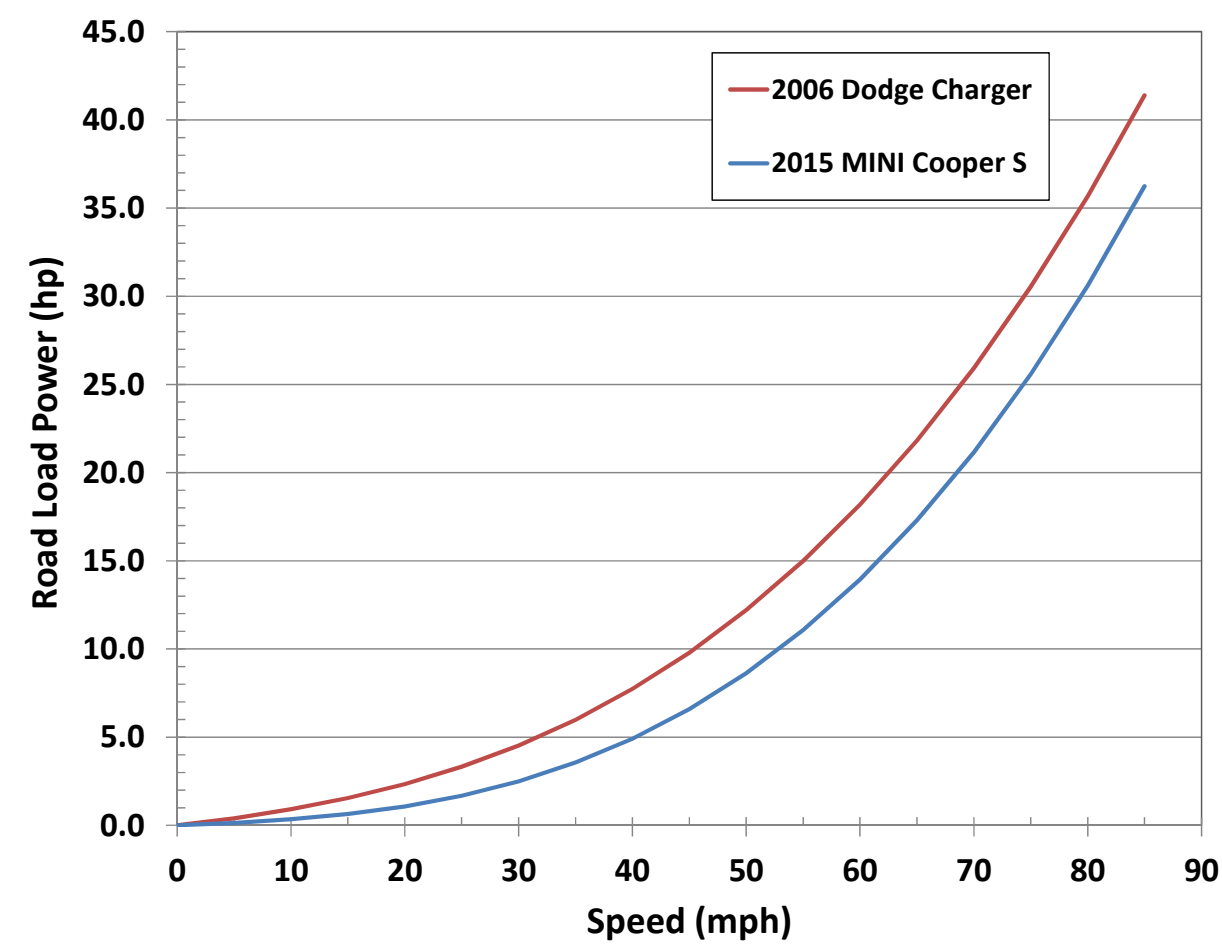

Figure 2. Road Load Horsepower for 2015 MINI Cooper S and 2006 Dodge Charger.

\section{$2.2 \quad$ FORD F150 ECOBOOST}

A 2016 Ford F150 pickup truck equipped with the 3.5-liter Ecoboost V6, turbocharged, direct-injection engine and 6-speed automatic transmission was provided by the Missouri Corn Growers Association to support these experiments. The vehicle was purchased new and engine break-in consisted of about 4500 miles of routine combined city/highway driving using retail E10. This break-in operation included several hundred miles of light-duty towing with a $2000 \mathrm{lb}$. trailer, and 600 miles with a $7000 \mathrm{lb}$. trailer. Upon delivery to the National Transportation Research Center (NTRC), engine oil was changed, and the truck was driven 500 miles at $80 \mathrm{mph}$ on the vehicle dynamometer to break-in or degreen the fresh oil before 
beginning baseline tests in the OEM condition. Oil temperature during this degreening protocol averaged $100-120 \mathrm{C}$ (which is in the normal range).

The manufacturer-recommended fuel for this F150 model is regular unleaded gasoline, but the owner's manual states that "to provide improved performance" premium fuel is recommended for severe duty usage such as towing ${ }^{23}$. The F150 test vehicle is shown in Figure 3. All tests with the Ford F150 were conducted at the ETW of $5250 \mathrm{lb}$.

During baseline testing at least five consecutive tests were run on each of the three drive cycles with the F150 (FTP, HFET, US06) plus a daily wide-open throttle (WOT) acceleration test. Particulate matter (PM) emissions were measured for the cold start portion of the FTP. The FTP is shown in Figure 4.

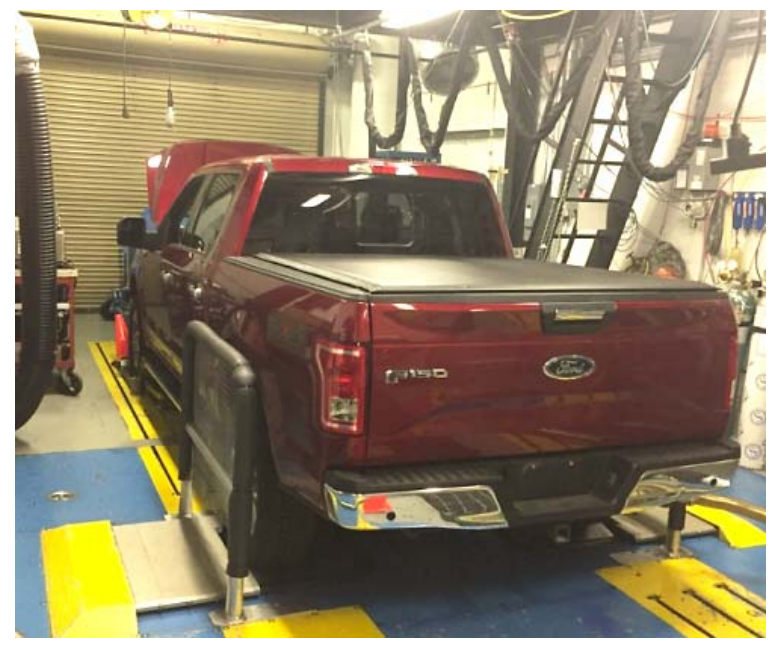

Figure 3. 2016 Ford F150 in the ORNL Vehicle Laboratory.

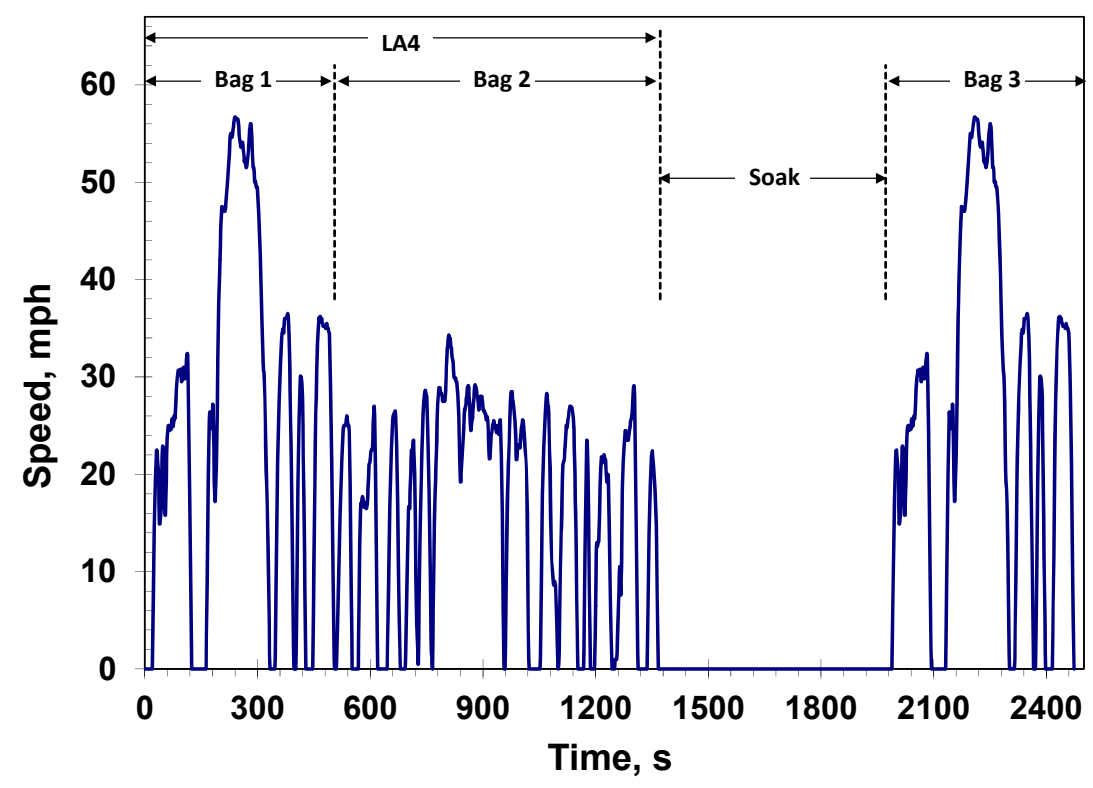

Figure 4. Federal Test Procedure for City Fuel Economy 
The FTP test is normally run in three phases, or "bags," and the final weighted result assumes a fourth bag (identical to bag 2) is run. The combination of Bag 1 and Bag 2 is known as the LA4 or the Urban Dynamometer Driving Schedule (UDDS). Six cold LA4 tests were run, with two tests per filter such that three PM measurements were made. PM emissions were not collected for the hot portion of the test; for modern gasoline engines, the hot portion of the test generally produces less than $10 \%$ of the total particulate emissions for the certification cycle ${ }^{24,25}$. Because of this tendency, collecting enough mass for accurate hot start measurement requires numerous hot tests a single filter.

After baseline testing, the F150 engine was removed and disassembled for installation of prototype highcompression pistons provided by MAHLE Powertrain. ${ }^{\ddagger}$ Factory compression ratio (CR) was measured on all six combustion chambers using a liquid volume technique before and after changing pistons.

Measurements of the OEM CR averaged 10.06:1, very close to the published 10.0:1 CR for this engine. The MAHLE-designed prototype pistons resulted in an average CR of 12.3:1, in good agreement with MAHLE's design target of 12.2:1. The OEM piston and MAHLE prototype piston are shown in Figure 5.

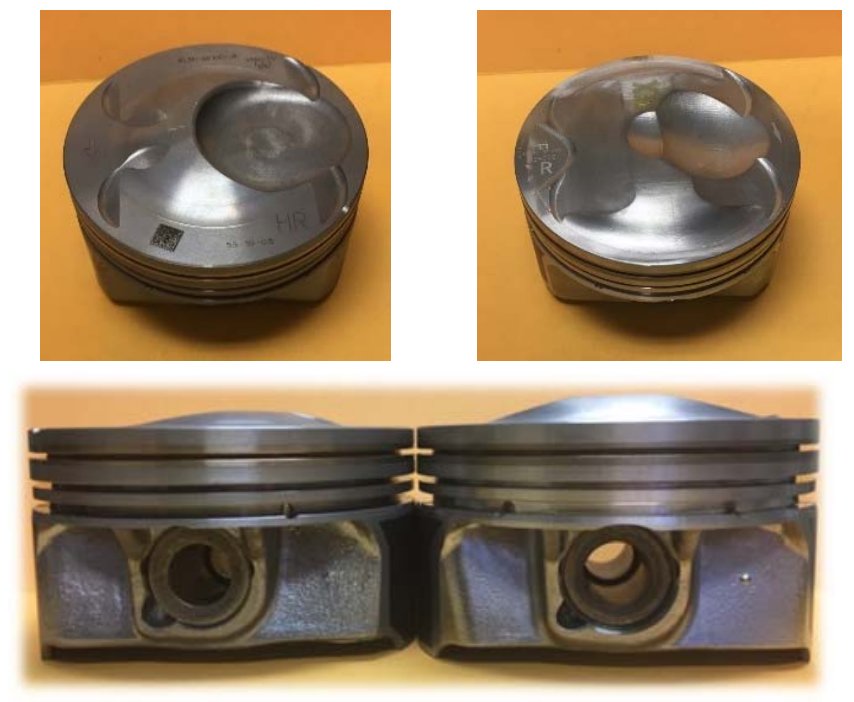

Figure 5. Ford F150 pistons. Factory piston on left, MAHLE prototype on right.

The piston rings were removed from the OEM pistons and installed on the prototype pistons while keeping each ring set in the same engine cylinder. To break-in the new pistons, the truck was driven over 2000 miles on public roads while towing a trailer at combined weight of 11,700 lb.; eight hours of WOT operation were achieved by driving the truck repeatedly up a steep grade. Fuel for the piston break-in was nominally E25 blended from retail premium E10 and E85. The vehicle was returned to the laboratory and subjected to the same fuel preparatory cycle used in baseline testing prior to conducting the E25 experiments with the high-CR pistons. No changes were made to the engine calibration or fuel system.

\section{$2.3 \quad$ TEST FACILITY}

The vehicles were evaluated in Oak Ridge National Laboratory's Vehicle Research Laboratory at the NTRC in Knoxville, TN. The vehicle research laboratory features a Burke E. Porter $300 \mathrm{hp} \mathrm{motor-in-the-}$ middle, two-wheel drive, 48-inch, single roll AC motoring chassis dynamometer. Gaseous vehicle emissions are measured with conventional gas analyzers sampling from a constant volume sampling (CVS) system (dilution tunnel) and the CVS bag sampling system. Reported results for fuel economy

\footnotetext{
¥ MAHLE Powertrain is a wholly-owned engineering services division of MAHLE GmbH. MAHLE GmbH is an automotive parts manufacturer that produces the OEM pistons for many vehicles, including the Ford F150 EcoBoost. http://www.us.mahle.com/
} 
were derived from fuel consumption measurements using an Emerson Micro Motion CMF010M, Coriolis-effect flow and density meter to measure instantaneous and cumulative fuel consumption. Fuel economy and $\mathrm{CO}_{2}$ emission levels also can be derived from the integrated emissions sampled from the CVS dilution tunnel using the carbon mass balance method specified by EPA and Code of Federal Regulations guidelines. Ambient temperature in the laboratory was maintained at $77^{\circ} \mathrm{F}(25 \mathrm{C}) \pm 5^{\circ} \mathrm{F}$ (2.8C) during all experiments, and combustion air for the engine intake was maintained at $77^{\circ} \mathrm{F}(25 \mathrm{C}) \pm$ $2^{\circ} \mathrm{F}(1.1 \mathrm{C})$ with $50 \%$ relative humidity.

Carbon-mass balance fuel economy and Coriolis fuel economy normally agree to within 1-2\%. Due to the variability in background $\mathrm{CO}_{2}$ and the impact of this measurement on carbon mass balance fuel economy, the Coriolis meter results are reported here. 


\section{TEST FUELS AND GASOLINE EQUIVALENT FUEL ECONOMY}

Tier 3 E10 certification fuel and the same base fuel blended with additional ethanol to produce a splashblended E25 were acquired from Gage Products for the study. These same fuels were used in an engine study led by Sluder ${ }^{14}$. Fuels were received with analysis results for properties such as octane numbers, density, net heating value, distillation, etc. To compute the particulate matter index ${ }^{26}$ (PMI), a detailed hydrocarbon analysis (DHA) was procured from Southwest Research Institute; along with this analysis additional repeat measurements of other relevant properties were conducted. Due to the challenges of accurately measuring net heating value and the desire to compare the E10 and E25 fuels on an energy equivalent basis, the average of the two heating value measurements was used for both fuels. ${ }^{\S}$ Selected fuel properties are shown in Table 2. The average of the two independent analyses are shown in bold for both the E10 and the E25 fuel.

To compare fuel economy for the experiments, all miles per gallon (mpg) measurements were converted to E0-equivalent mpg, or MPGge (miles per gallon, gasoline equivalent). This method permits direct comparison for a clear understanding of any changes in vehicle efficiency. Rather than report miles per BTU (or km per MJ), MPGge provides a convenient measure that readers are familiar with, which is comparable to regulatory fuel economy.

MPGge is calculated by the following relation:

$$
M P G_{g e}=\text { test fuel } M P G \times \frac{\text { reference fuel BTU/gal }}{\text { test fuel BTU/gal }}
$$

For these experiments, the reference fuel was the ethanol-free (E0) Federal Certification Gasoline ("indolene") which was in use in 1975 and is still the basis for corporate average fuel economy (CAFE) calculations. This fuel has a net heating value of $114,095 \mathrm{BTU} / \mathrm{gal}^{27,28,29}$.

It is important to note that the reference fuel described above was not used in any of these experiments; it is merely a standard gasoline for computing MPGge. In this way, results would be similar to those used for regulatory fuel economy compliance if E0-equivalent fuel economy was the benchmark when ethanol blends are used.*

Reported average fuel economies for multiple tests were calculated using the harmonic mean of the multiple test results using the following equation:

$$
\mathrm{MPG}_{\mathrm{avg}}=\frac{n}{\sum_{i=1}^{n} \frac{1}{\mathrm{MPG}_{i}}}
$$

\footnotetext{
$\S$ It is also common to compute the NHV of the ethanol blend, assuming the base fuel NHV is correct and simply accounting for the added ethanol. This approach yields an NHV for the E25 slightly lower than the average of the two analyses. Using the lower NHV improves the E25 MPGge; to be conservative, we use the average of the two independent analyses.

${ }^{* *}$ Fuel economy for regulatory compliance is currently adjusted as described in references 27-29, using an adjustment factor known as the " $\mathrm{R}$ factor." The $\mathrm{R}$ factor is defined as the percent change in fuel economy divided by the percent change in energy density, to allow for mpg adjustment back to a 1975 standard fuel when there are small variations in heating value of ethanol-free Federal Certification Gasoline. $\mathrm{R}$ is currently 0.6 , but published studies (refs 28-29) have shown that $\mathrm{R}$ for modern vehicles should be around $0.93-0.96$. This topic is too complex to discuss thoroughly in this report; the reader is encouraged to refer to references 27-29. For the E0-equivalent or MPGge results presented here, the authors are essentially assuming R=1.0.
} 
Table 2. Selected Properties of Test Fuels.

\begin{tabular}{|c|c|c|c|c|c|c|c|}
\hline \multirow{2}{*}{$\begin{array}{l}\text { Property } \\
\text { (Units) }\end{array}$} & \multirow[b]{2}{*}{ Method } & \multicolumn{3}{|c|}{ Tier 3 E10 } & \multicolumn{3}{|c|}{ "Tier 3 E25" } \\
\hline & & $\begin{array}{l}\text { Gage } \\
\text { CofA }\end{array}$ & SwRI & E10 Avg & $\begin{array}{l}\text { Gage } \\
\text { CofA }\end{array}$ & SwRI & E25 Avg \\
\hline RON & ASTM D2699 & 92.3 & 92.2 & 92.3 & 98.9 & 98.5 & 98.7 \\
\hline MON & ASTM D2700 & 84.5 & 84.2 & 84.4 & 87.5 & 86.9 & 87.2 \\
\hline Sensitivity & RON-MON & 7.8 & 8.0 & 7.9 & 11.4 & 11.6 & 11.5 \\
\hline $\begin{array}{l}\text { Antiknock } \\
\text { Index }\end{array}$ & $(\mathrm{RON}+\mathrm{MON}) / 2$ & 88.4 & 88.2 & 88.3 & 93.2 & 92.7 & 93.0 \\
\hline $\begin{array}{c}\text { Carbon } \\
\text { Content }(w t \%) \\
\end{array}$ & ASTM D5291 & 82.81 & 83.14 & 82.98 & 77.39 & 77.33 & 77.36 \\
\hline $\begin{array}{c}\text { Hydrogen } \\
\text { Content }(w t \%)\end{array}$ & ASTM D5291 & 13.53 & 13.7 & 13.62 & 13.40 & 13.48 & 13.44 \\
\hline $\begin{array}{c}\text { Oxygen } \\
\text { Content }(w t \%)\end{array}$ & $\begin{array}{l}\text { ASTM D4815 } \\
\text { ASTM D5599 }\end{array}$ & $\begin{array}{c}3.66 \\
- \\
\end{array}$ & $\begin{array}{c}- \\
3.56\end{array}$ & 3.61 & $\begin{array}{c}9.22 \\
-\end{array}$ & $\begin{array}{c}- \\
8.85\end{array}$ & 9.04 \\
\hline $\begin{array}{c}\text { Net Heat of } \\
\text { Combustion } \\
(\mathrm{MJ} / \mathrm{kg}) \\
\end{array}$ & $\begin{array}{l}\text { ASTM D240 } \\
\text { ASTM D4809 }\end{array}$ & $\begin{array}{c}41.43 \\
- \\
\end{array}$ & $\begin{array}{c}- \\
41.689 \\
\end{array}$ & 41.56 & $\begin{array}{c}39.12 \\
- \\
\end{array}$ & $\begin{array}{c}- \\
39.064 \\
\end{array}$ & 39.09 \\
\hline $\begin{array}{c}\text { Specific } \\
\text { Gravity (60F) }\end{array}$ & ASTM D4052 & 0.7482 & 0.7480 & 0.7481 & .7552 & 0.7555 & 0.7553 \\
\hline $\begin{array}{c}\text { Density } \\
\text { (g/cc 15C) }\end{array}$ & ASTM D4052 & 0.7475 & 0.7477 & 0.7476 & 0.7545 & 0.7553 & 0.7549 \\
\hline $\begin{array}{c}\text { Ethanol } \\
\text { Content (vol\%) }\end{array}$ & $\begin{array}{l}\text { ASTM D4815 } \\
\text { ASTM D5599 }\end{array}$ & 9.93 & 9.67 & 9.80 & $\begin{array}{c}25.27 \\
-\end{array}$ & $\begin{array}{c}- \\
24.26 \\
\end{array}$ & 24.765 \\
\hline $\begin{array}{c}\text { Particulate } \\
\text { Matter Index }^{22}\end{array}$ & [Ref 22] & - & 1.924 & 1.924 & - & 1.550 & 1.550 \\
\hline Water (ppm) & ASTM E1064 & 1192 & - & 1192 & 2676 & - & 2676 \\
\hline
\end{tabular}

RON=Research Octane Number; MON=Motor Octane Number; CofA=Certificate of Analysis; SwRI=Southwest Research Institute; 


\section{RESULTS}

While the test fuels for the two vehicles were the same, the test plans were different. As such, results are separated by vehicle type.

\subsection{MINI COOPER FUEL ECONOMY/EFFICIENCY}

Baseline experiments with Tier 3 E10 for FTP, HFET, and US06 fuel economy tests were conducted in duplicate for the MINI Cooper with the EPA shift schedule at its $3125 \mathrm{lb}$. ETW and at the $4500 \mathrm{lb}$. Dodge Charger ETW. The FTP and HFET were repeated using a revised shift schedule as shown in Table 1 to simulate downspeeding for both test weights. After switching to E25, the vehicle was thoroughly prepared to ensure adaptation to the new fuel using the same rigorous protocol developed during the MidLevel Ethanol blends program ${ }^{17,18}$. Experiments with E25 were conducted in duplicate at both test weights. Downspeeding (via short-shifting per Table 1) was employed on all tests except the US06, due to its high power demand. Average fuel economy results are shown in Table 3 and Figures 6-8. Range bars in the figures show the maximum and minimum of the duplicate (and occasional triplicate) tests. Reported fuel economy is in MPGge, as described above. FTP results are shown in Figure 6.

Table 3. Average fuel economy in MPGge for MINI Cooper S experiments at two test weights with two fuels with two shift schedules.

\begin{tabular}{|c|c|c|c|c|c|}
\hline $\begin{array}{l}\text { Test weight and } \\
\text { Road Load }\end{array}$ & Fuel & Shift Schedule & $\begin{array}{c}\text { FTP } \\
\text { MPGge } \\
\end{array}$ & $\begin{array}{c}\text { HFET } \\
\text { MPGge } \\
\end{array}$ & $\begin{array}{c}\text { US06 } \\
\text { MPGge }\end{array}$ \\
\hline \multirow{4}{*}{$\begin{array}{l}\text { MINI Cooper, } \\
3125 \text { lb }\end{array}$} & \multirow{2}{*}{ E10 } & EPA & 28.8 & 45.7 & 31.8 \\
\hline & & Downspeed & 31.6 & 48.0 & - \\
\hline & \multirow{2}{*}{ E25 } & EPA & - & - & 32.6 \\
\hline & & Downspeed & 31.3 & 48.0 & - \\
\hline \multirow{4}{*}{$\begin{array}{c}\text { Dodge Charger } \\
\text { Emulation, } \\
4500 \mathrm{lb}\end{array}$} & \multirow{2}{*}{ E10 } & EPA & 25.3 & 38.8 & 25.1 \\
\hline & & Downspeed & 26.3 & 39.8 & - \\
\hline & \multirow{2}{*}{ E25 } & EPA & 25.3 & 39.0 & 26.3 \\
\hline & & Downspeed & 26.8 & 40.3 & - \\
\hline
\end{tabular}

FTP=Federal Test Procedure; HFET=Highway Fuel Economy Test; US06=high-load, high-speed test; MPGge=miles per gallon gasoline equivalent; EPA=Environmental Protection Agency

With fuel economy given in MPGge, differences in energy density do not confound understanding the results from an efficiency perspective; higher MPGge indicates higher efficiency. Downspeeding improves the efficiency on the FTP by about $9 \%$ at the $3125 \mathrm{lb}$. test weight with regular E10. This result implies that the MINI Cooper is not significantly knock-limited on the FTP even with downspeeding. Increasing the test weight and road load significantly reduces the fuel economy, as expected, but downspeeding shows an efficiency gain with both fuels. At the higher test weight, the MINI Cooper responds to the high-octane E25 with over 5\% improvement for the downsped case compared to the E10 baseline. 
Results for the HFET are shown in Figure 7. Downspeeding returns an efficiency gain at both test weights and with both fuels. For most vehicles the HFET is not a significantly knock-limited test, due to its mild accelerations and a top speed of only $60 \mathrm{mph}$. For this test, the high-octane E25 returns only a slight increase in efficiency above the E10 fuel at both test weights.

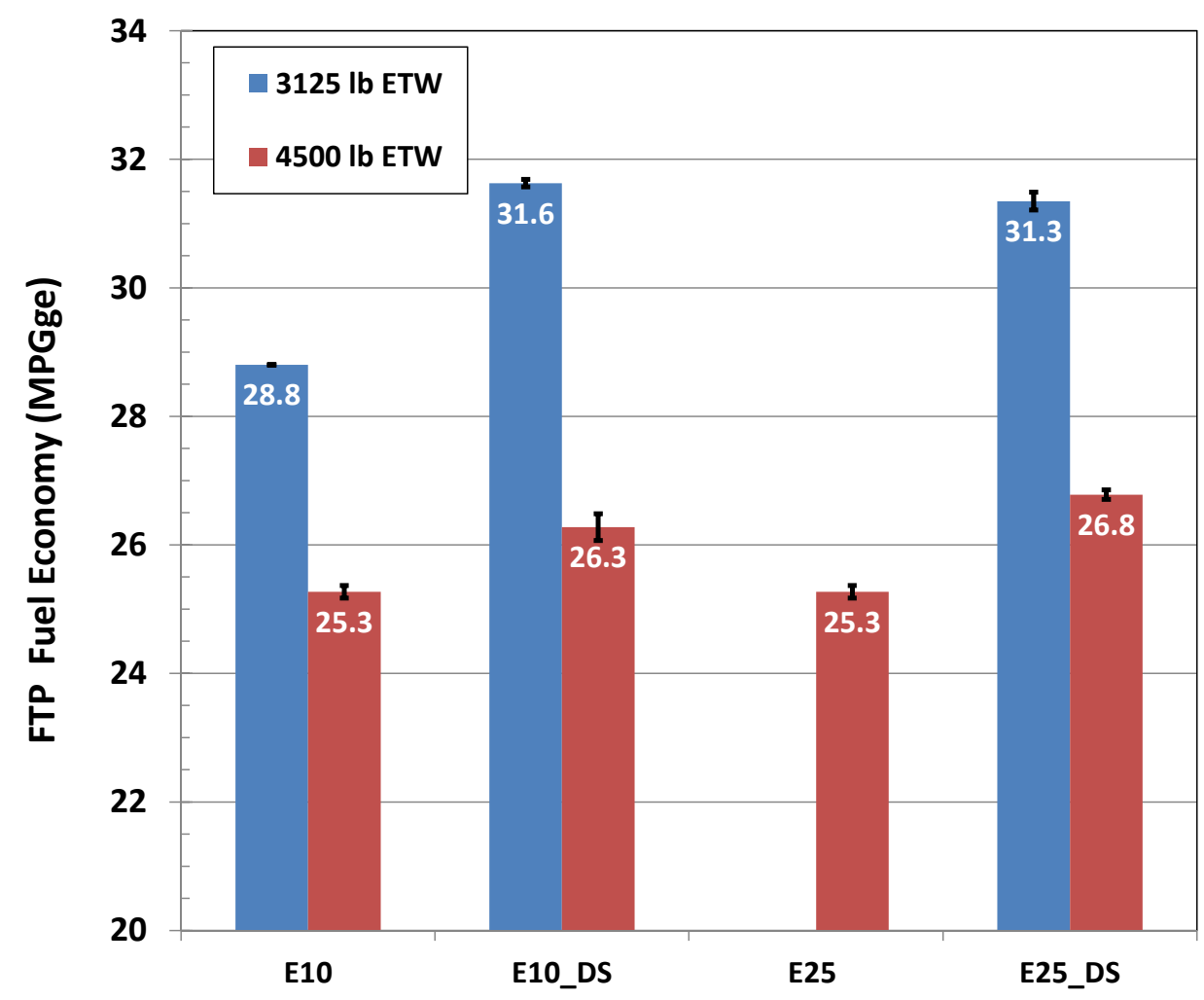

Figure 6. FTP Fuel Economy for MINI Cooper S at two test weights, with two fuels, and two shift schedules. Range bars indicate maximum and minimum for multiple tests. "DS" indicates downspeeding.

Results for the high-speed, high-load US06 test are shown in Figure 8. Due to the high power demand of the US06 test, only the EPA shift schedule was used. At both test weights the high-octane E25 provides an efficiency gain; this gain is over $2 \%$ at the factory test weight of 3125 and over $4 \%$ for the heavier Dodge Charger emulation at $4500 \mathrm{lb}$. 


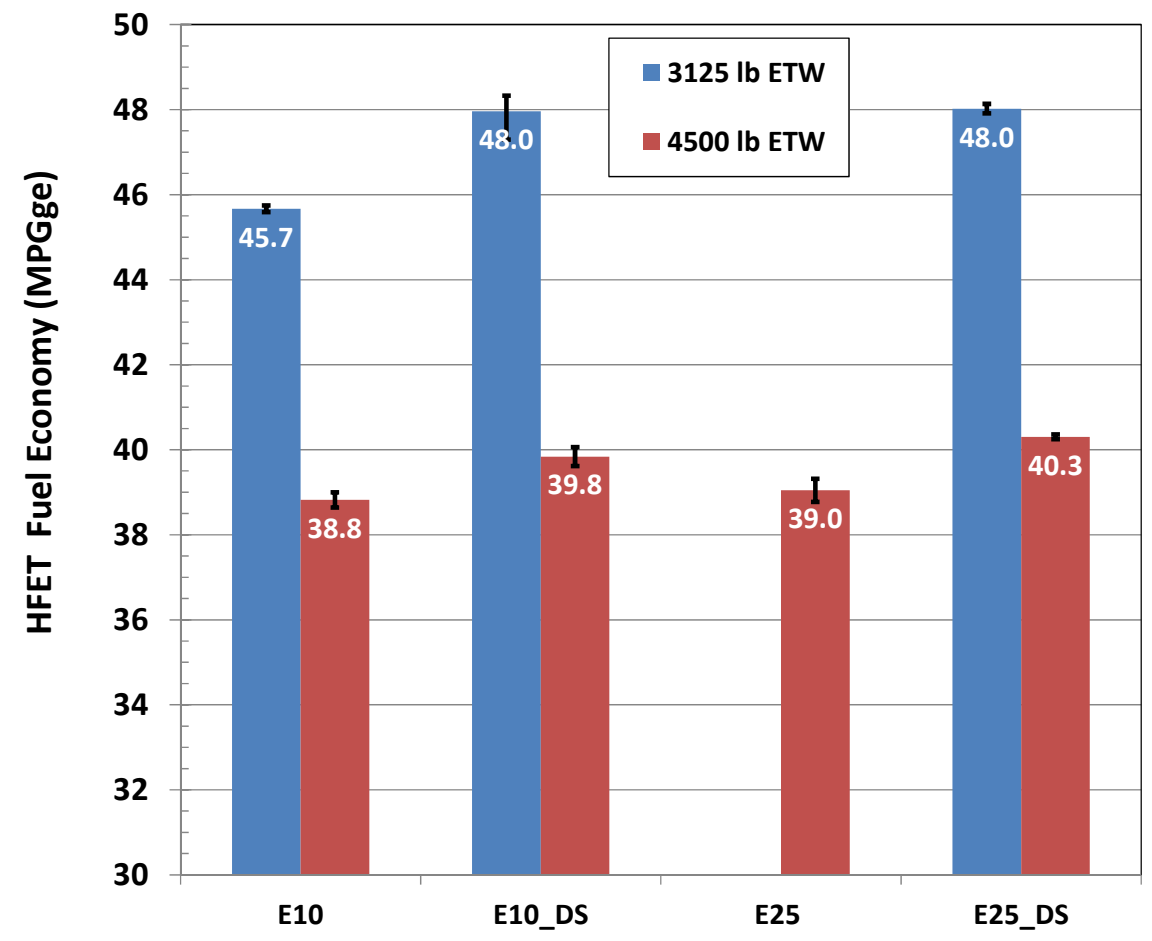

Figure 7. Highway Fuel Economy Test Results for MINI Cooper S at two test weights, with two fuels and two shift schedules. Range bars indicate maximum and minimum for multiple tests. "DS" indicates downspeeding.

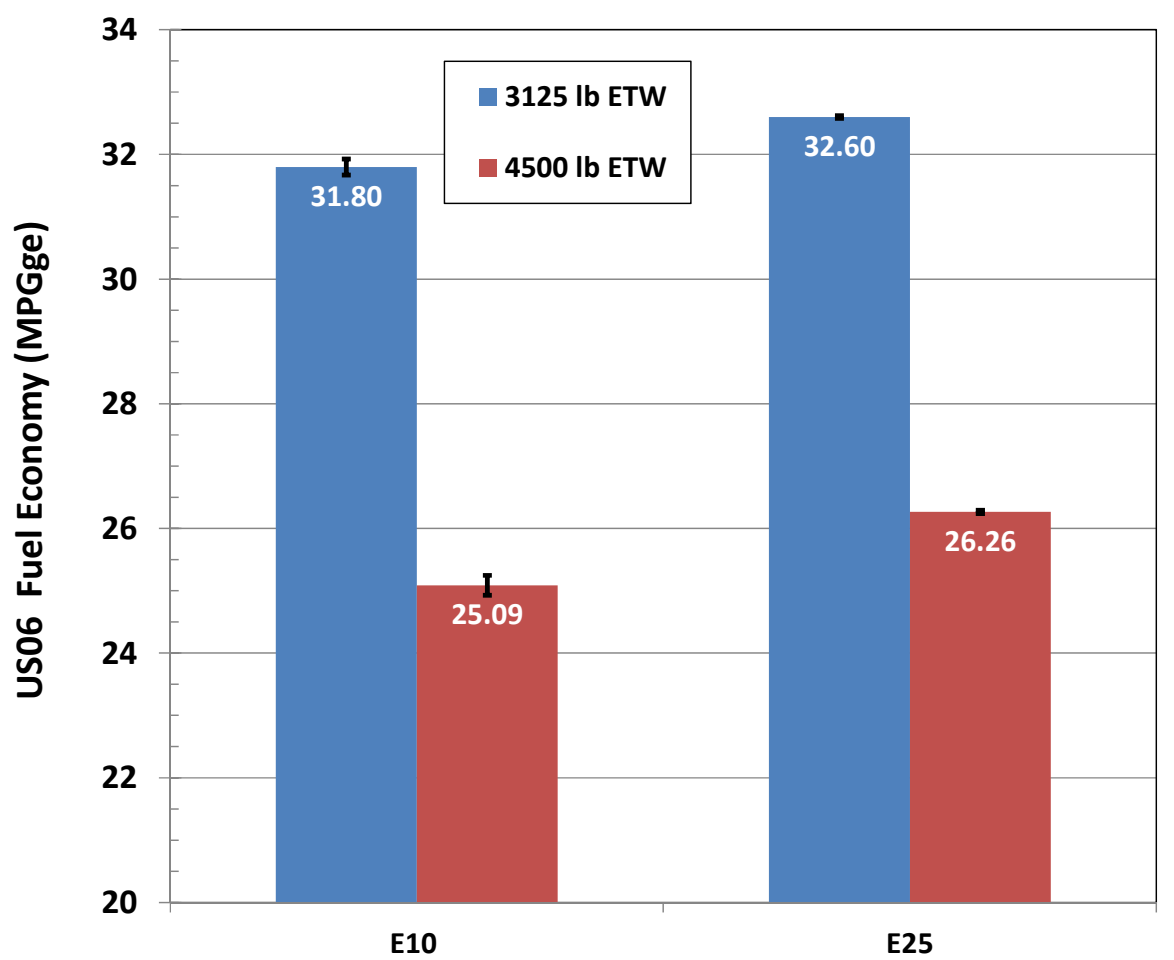

Figure 8. US06 Fuel Economy for MINI Cooper S at two test weights with two fuels. Range bars indicate maximum and minimum for multiple tests. 


\subsection{MINI COOPER VEHICLE EMISSIONS}

Average emissions results for all tests are shown in Tables 4-7. Bar charts show average emissions results and range bars indicate the maximum and minimum measurements for duplicate or triplicate tests.

Nonmethane organic gas (NMOG) emissions were calculated from nonmethane hydrocarbons (NMHC) per the method developed during the DOE Mid-Level Ethanol Blends Program ${ }^{30,31}$ and subsequently adopted by the $\mathrm{EPA}^{32}$. Oxides of nitrogen $(\mathrm{NOx}), \mathrm{NMOG}+\mathrm{NOx}$, and carbon monoxide $(\mathrm{CO})$ are also reported.

The 2015 MINI Cooper S is certified to Tier 3, Bin 30 standards $(0.030 \mathrm{~g} / \mathrm{mile}$ NMOG+NOx, $1.0 \mathrm{~g} / \mathrm{mi}$ $\mathrm{CO})$. In 2015, the certification fuel would have been ethanol-free federal certification gasoline, but as noted earlier, the MINI Cooper Owner's Manua ${ }^{19}$ states that fuels with $25 \%$ ethanol may be used. Beginning in model year 2017, manufacturers began to phase in emissions certification testing with Tier 3 E10 fuel such as the base fuel used here.

Table 4. Average NMOG Emissions for MINI Cooper S experiments at two test weights with two fuels and two shift schedules.

\begin{tabular}{|c|c|c|c|c|c|}
\hline $\begin{array}{l}\text { Test weight and } \\
\text { Road Load }\end{array}$ & Fuel & Shift Schedule & $\begin{array}{c}\text { FTP NMOG } \\
\mathrm{mg} / \mathrm{mi}\end{array}$ & $\begin{array}{c}\text { HFET NMOG } \\
\mathrm{mg} / \mathrm{mi}\end{array}$ & $\begin{array}{c}\text { US06 NMOG } \\
\mathrm{mg} / \mathrm{mi}\end{array}$ \\
\hline \multirow{4}{*}{$\begin{array}{l}\text { MINI Cooper, } \\
3125 \mathrm{lb}\end{array}$} & \multirow{2}{*}{ E10 } & EPA & 13.5 & 1.0 & 4.9 \\
\hline & & Downspeed & 9.2 & 1.5 & - \\
\hline & \multirow{2}{*}{ E25 } & EPA & - & - & 1.1 \\
\hline & & Downspeed & 14.5 & 1.1 & - \\
\hline \multirow{4}{*}{$\begin{array}{c}\text { Dodge Charger } \\
\text { Emulation, } \\
4500 \mathrm{lb}\end{array}$} & \multirow{2}{*}{ E10 } & EPA & 18.3 & 1.1 & 6.2 \\
\hline & & Downspeed & 16.9 & 1.5 & - \\
\hline & \multirow{2}{*}{ E25 } & EPA & 16.8 & 0.9 & 7.2 \\
\hline & & Downspeed & 17.3 & 2.1 & - \\
\hline
\end{tabular}

FTP=Federal Test Procedure; HFET=Highway Fuel Economy Test; US06=high-load, high-speed test; EPA=Environmental Protection Agency

Table 5. Average NOx Emissions for MINI Cooper S experiments at two test weights with two fuels and two shift schedules.

\begin{tabular}{|c|c|c|c|c|c|}
\hline $\begin{array}{l}\text { Test weight and } \\
\text { Road Load }\end{array}$ & Fuel & Shift Schedule & $\begin{array}{c}\text { FTP NOx } \\
\text { mg/mi }\end{array}$ & $\begin{array}{c}\text { HFET NOx } \\
\mathrm{mg} / \mathrm{mi}\end{array}$ & $\begin{array}{c}\text { US06 NOx } \\
\text { mg/mi }\end{array}$ \\
\hline \multirow{4}{*}{$\begin{array}{l}\text { MINI Cooper, } \\
3125 \mathrm{lb}\end{array}$} & \multirow{2}{*}{ E10 } & EPA & 11.1 & 0.3 & 7.5 \\
\hline & & Downspeed & 7.6 & 0.3 & - \\
\hline & \multirow{2}{*}{ E25 } & EPA & - & - & 6.9 \\
\hline & & Downspeed & 9.4 & 0.2 & - \\
\hline \multirow{4}{*}{$\begin{array}{l}\text { Dodge Charger } \\
\text { Emulation, } \\
4500 \mathrm{lb}\end{array}$} & \multirow{2}{*}{ E10 } & EPA & 12.4 & 0.4 & 27.6 \\
\hline & & Downspeed & 10.1 & 0.5 & - \\
\hline & \multirow{2}{*}{ E25 } & EPA & 8.6 & 0.5 & 10.5 \\
\hline & & Downspeed & 10.8 & 0.4 & - \\
\hline
\end{tabular}

FTP=Federal Test Procedure; HFET=Highway Fuel Economy Test; US06=high-load, high-speed test; EPA=Environmental Protection Agency 
The test matrix for emissions measurement was the same as for the fuel economy results shown in Table 3. Table 4 shows the average NMOG result for duplicate tests for both the Tier 3 E10 and the splashblended "Tier 3 E25." Results for NOx are given in Table 5, NMOG+NOx in Table 6, and CO emissions results are provided in Table 7.

Table 6. Average NMOG+NOx Emissions for MINI Cooper S experiments at two test weights with two fuels and two shift schedules.

\begin{tabular}{|c|c|c|c|c|c|}
\hline $\begin{array}{l}\text { Test weight and } \\
\text { Road Load }\end{array}$ & Fuel & Shift Schedule & $\begin{array}{c}\text { FTP } \\
\text { NMOG+NOx } \\
\mathrm{mg} / \mathrm{mi}\end{array}$ & $\begin{array}{c}\text { HFET } \\
\text { NMOG+NOx } \\
\text { mg/mi }\end{array}$ & $\begin{array}{c}\text { US06 } \\
\text { NMOG+NOx } \\
\text { mg/mi }\end{array}$ \\
\hline \multirow{4}{*}{$\begin{array}{l}\text { MINI Cooper, } \\
3125 \mathrm{lb}\end{array}$} & \multirow{2}{*}{ E10 } & EPA & 24.7 & 1.2 & 12.4 \\
\hline & & Downspeed & 16.7 & 1.8 & - \\
\hline & \multirow{2}{*}{ E25 } & EPA & - & - & 8.0 \\
\hline & & Downspeed & 23.9 & 1.4 & - \\
\hline \multirow{4}{*}{$\begin{array}{c}\text { Dodge Charger } \\
\text { Emulation, } \\
4500 \mathrm{lb}\end{array}$} & \multirow{2}{*}{ E10 } & EPA & 30.6 & 1.5 & 33.8 \\
\hline & & Downspeed & 27.0 & 1.9 & - \\
\hline & \multirow{2}{*}{ E25 } & EPA & 25.4 & 1.4 & 17.7 \\
\hline & & Downspeed & 28.2 & 2.5 & - \\
\hline \multicolumn{3}{|c|}{ EPA Tier 3, Bin 30 Emissions Standard } & 30.0 & 30.0 & NDA \\
\hline
\end{tabular}

FTP=Federal Test Procedure; HFET=Highway Fuel Economy Test; US06=high-load, high-speed test; EPA=Environmental Protection Agency; NDA=not directly applicable;

Supplemental Federal Test Procedure $=0.35 * \mathrm{FTP}+0.28 * \mathrm{US} 06+0.37 * \mathrm{SC} 03 \leq 50 \mathrm{mg} / \mathrm{mi} ; \mathrm{SC} 03=$ air conditioning test

Table 7. Average CO Emissions for MINI Cooper S experiments at two test weights with two fuels and two shift schedules.

\begin{tabular}{cccccc}
\hline $\begin{array}{c}\text { Test weight and } \\
\text { Road Load }\end{array}$ & Fuel & Shift Schedule & $\begin{array}{c}\text { FTP CO } \\
\mathbf{m g} / \mathbf{m i}\end{array}$ & $\begin{array}{c}\text { HFET CO } \\
\mathbf{m g} / \mathbf{m i}\end{array}$ & $\begin{array}{c}\text { US06 CO } \\
\mathbf{m g} / \mathbf{m i}\end{array}$ \\
\hline \multirow{3}{*}{$\begin{array}{c}\text { MINI Cooper, } \\
\mathbf{3 1 2 5} \text { lb }\end{array}$} & \multirow{2}{*}{ E10 } & EPA & 186 & 231 & 776 \\
\cline { 2 - 5 } & \multirow{2}{*}{ E25 } & Downspeed & 152 & 187 & - \\
\cline { 2 - 5 } & \multirow{2}{*}{ E10 } & EPA & - & - & 577 \\
\hline \multirow{2}{*}{$\begin{array}{c}\text { Dodge Charger } \\
\text { Emulation, } \\
\mathbf{4 5 0 0} \text { lb }\end{array}$} & \multirow{2}{*}{ E25 } & Eownspeed & 120 & 182 & - \\
\cline { 2 - 5 } & & Downspeed & 353 & 254 & 1270 \\
\hline EPA Tier 3, Bin 30 Emissions Standard & 294 & 287 & - \\
\hline
\end{tabular}

FTP=Federal Test Procedure; HFET=Highway Fuel Economy Test; US06=high-load, high-speed test; EPA=Environmental Protection Agency; NDA=not directly applicable;

Supplemental Federal Test Procedure $=0.35 * \mathrm{FTP}+0.28 * \mathrm{US} 06+0.37 * \mathrm{SC} 03 \leq 4200 \mathrm{mg} / \mathrm{mi} ; \mathrm{SC} 03=$ air conditioning test 
Emissions results for the FTP are shown in Figures 9-12, and US06 results are shown in Figures 13-16. Emissions results for the HFET are extremely low and not shown in figures.

For the FTP test results in Figures 9-12, NMOG, NOx, and NMOG+NOx emissions show no strong fuel effect or shift schedule effect. Emissions are marginally higher for the $4500 \mathrm{lb}$. Charger emulation, but remain quite low, and possibly within the Tier 3 Bin 30 limit. Carbon Monoxide emissions are quite low, as shown in Figure 12, well within the $1.0 \mathrm{~g} / \mathrm{mi}$ limit. The addition of ethanol reduces $\mathrm{CO}$ emissions, consistent with prior studies ${ }^{17,18}$.

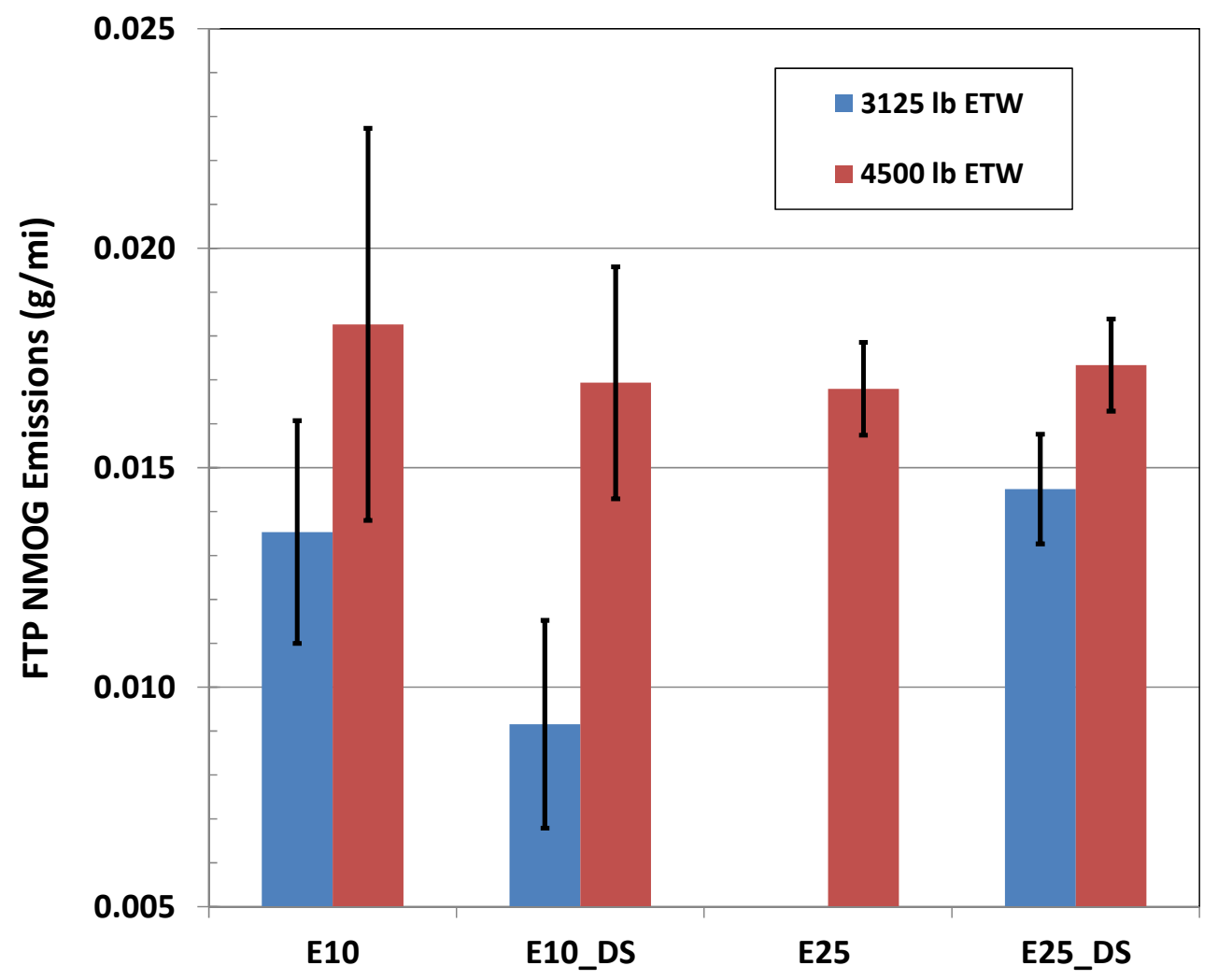

Figure 9. FTP NMOG emissions for 2015 MINI Cooper at two test weights, with two fuels and two shift schedules. Range bars indicate maximum and minimum for multiple tests. "DS" indicates downspeeding.

The US06 emissions results for both fuels and test weights are shown in Figures 13-16. NMOG (Figure 13), NOx (Figure 14), and NMOG+NOx (Figure 15) emissions are quite low but higher at the $4500 \mathrm{lb}$. test weight. The US06 is part of the Supplemental Federal Test Procedure (SFTP), which also includes an SC03 air-conditioning test (not included in this test program), so these results cannot be compared directly to a specific US06 standard. As a point of reference, for model year 2017, the SFTP standard was $103 \mathrm{NMOG}+\mathrm{NOx} \mathrm{mg} / \mathrm{mi}$, and $4.2 \mathrm{~g} \mathrm{CO} / \mathrm{mi}$. The SFTP is calculated from 35\% FTP, 28\% US06, and 37\% of the SC03. As such, the FTP and US06 contribute 63\% of the weighted SFTP NMOG+NOx; at the Charger ETW the MINI Cooper produces $13.4 \%$ of the standard on these two tests, leaving a comfortable margin for the $\mathrm{SC} 03$. 


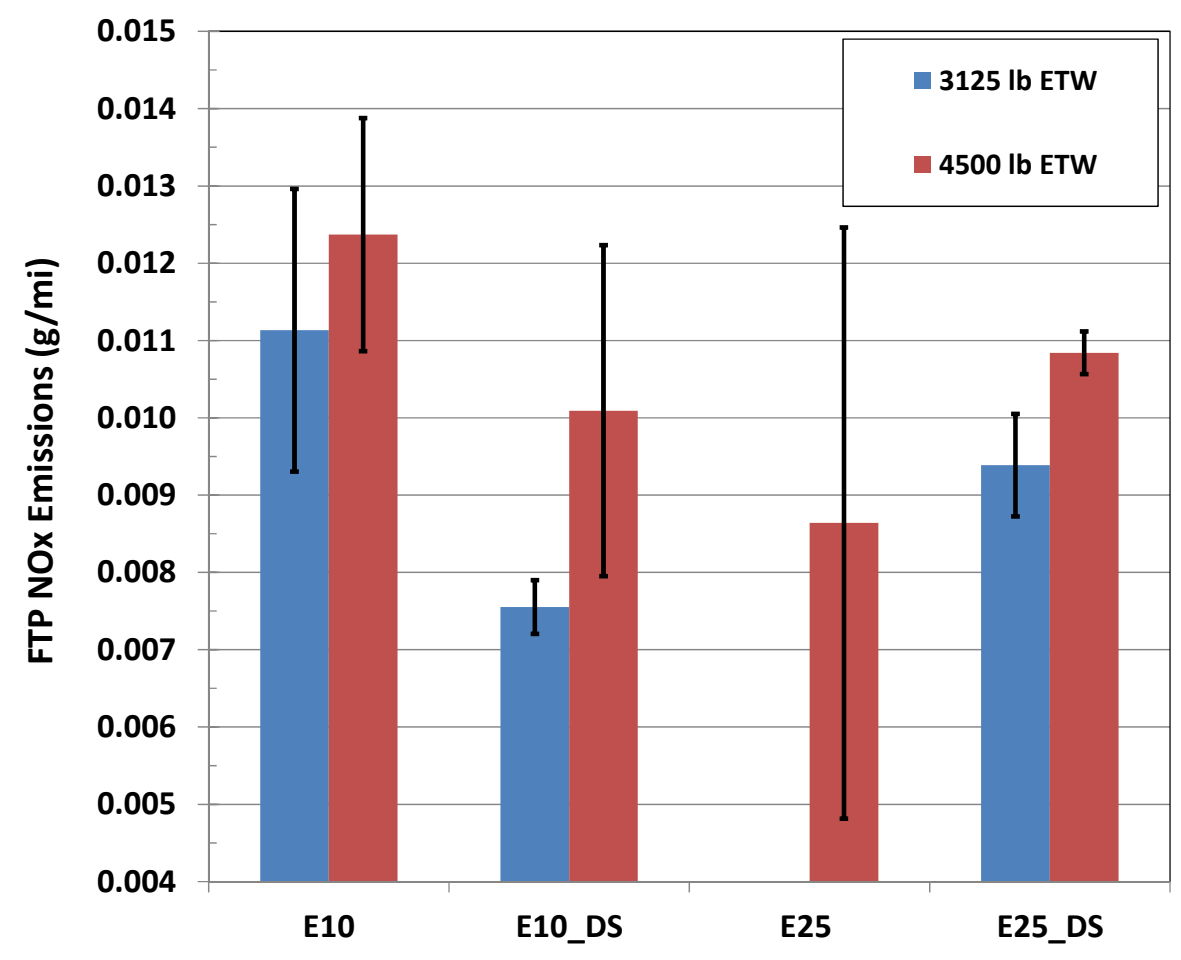

Figure 10. FTP NOx emissions for 2015 MINI Cooper at two test weights, with two fuels and two shift schedules. Range bars indicate maximum and minimum for multiple tests. "DS" indicates downspeeding.

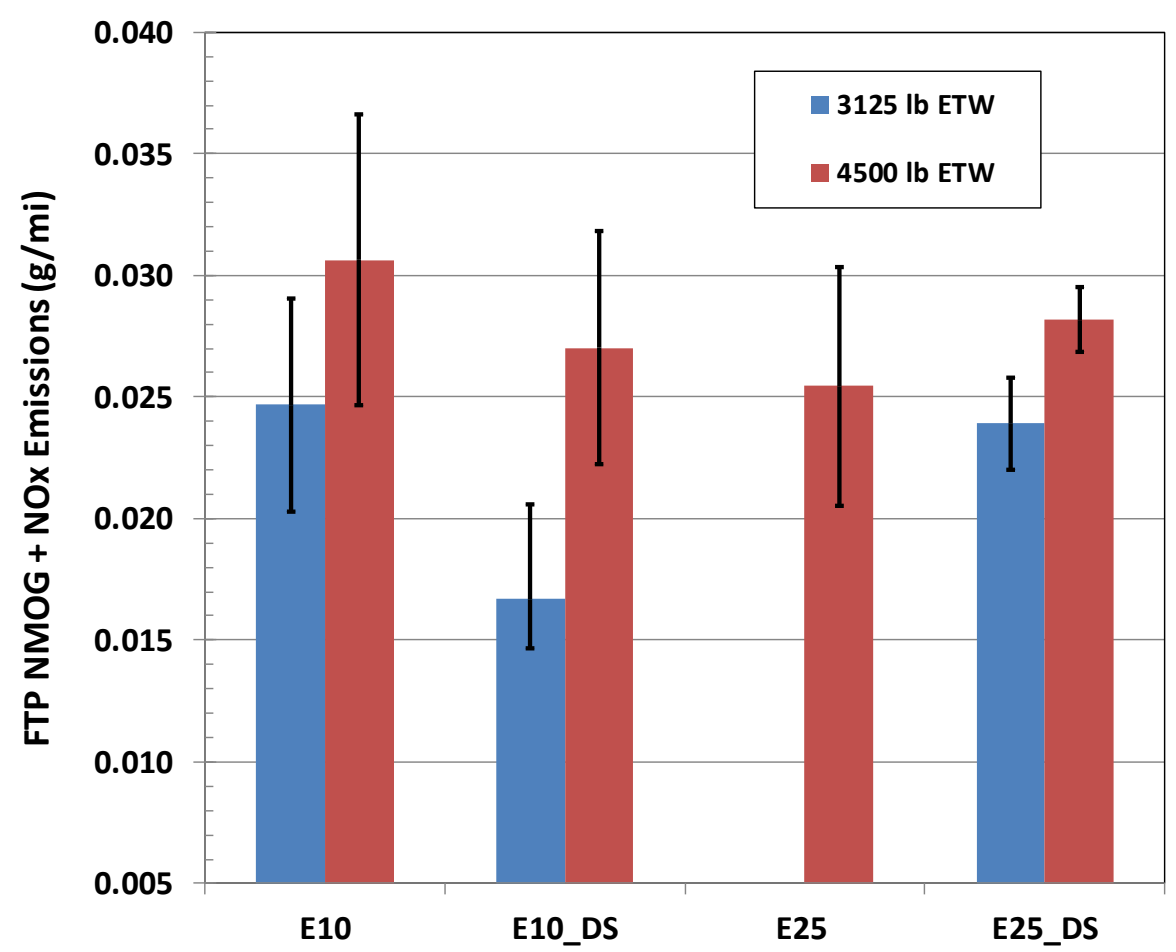

Figure 11. FTP NMOG + NOx emissions for 2015 MINI Cooper at two test weights, with two fuels and two shift schedules. Range bars indicate maximum and minimum for multiple tests. "DS" indicates downspeeding. 


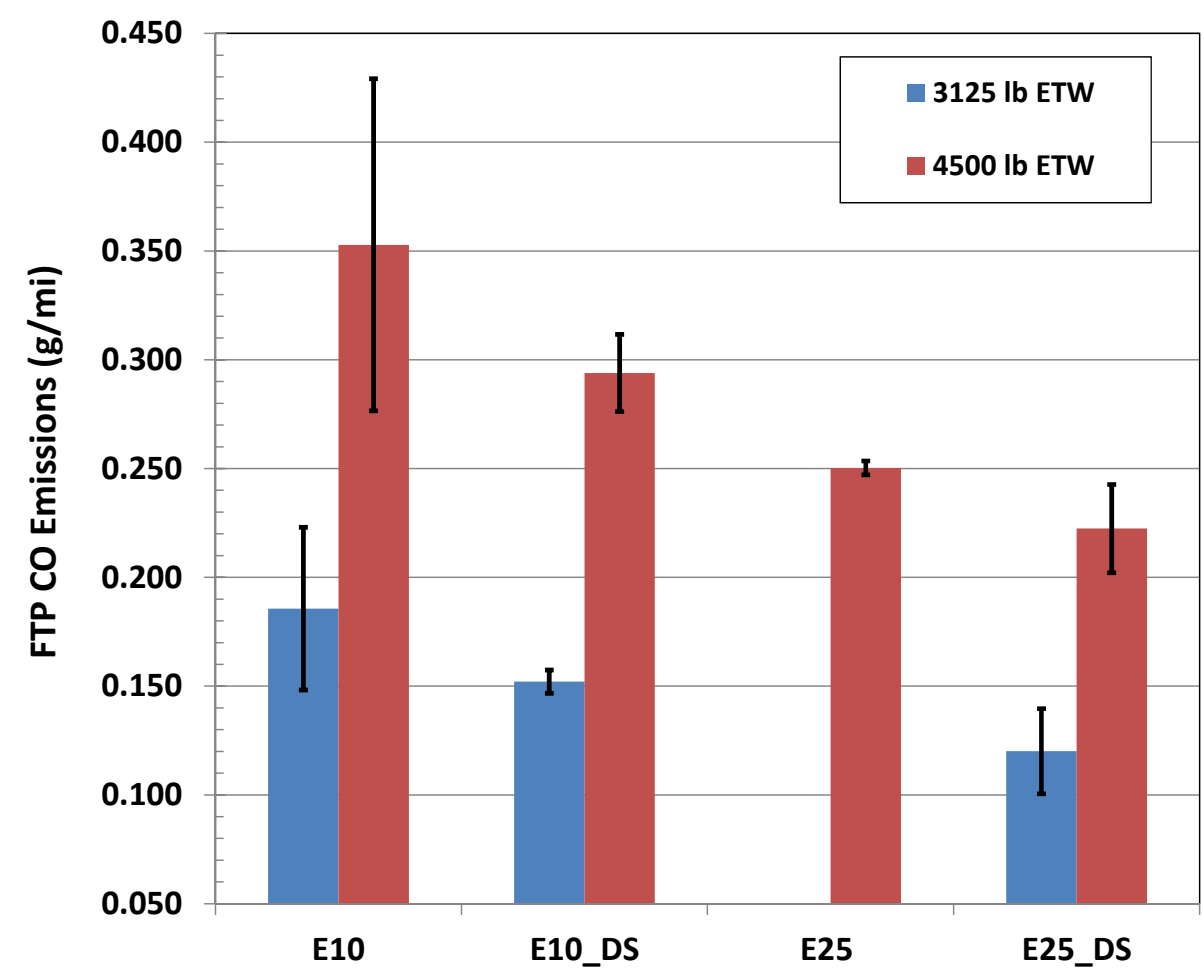

Figure 12. FTP CO emissions for 2015 MINI Cooper at two test weights, with two fuels and two shift schedules. Range bars indicate maximum and minimum for multiple tests. "DS" indicates downspeeding.

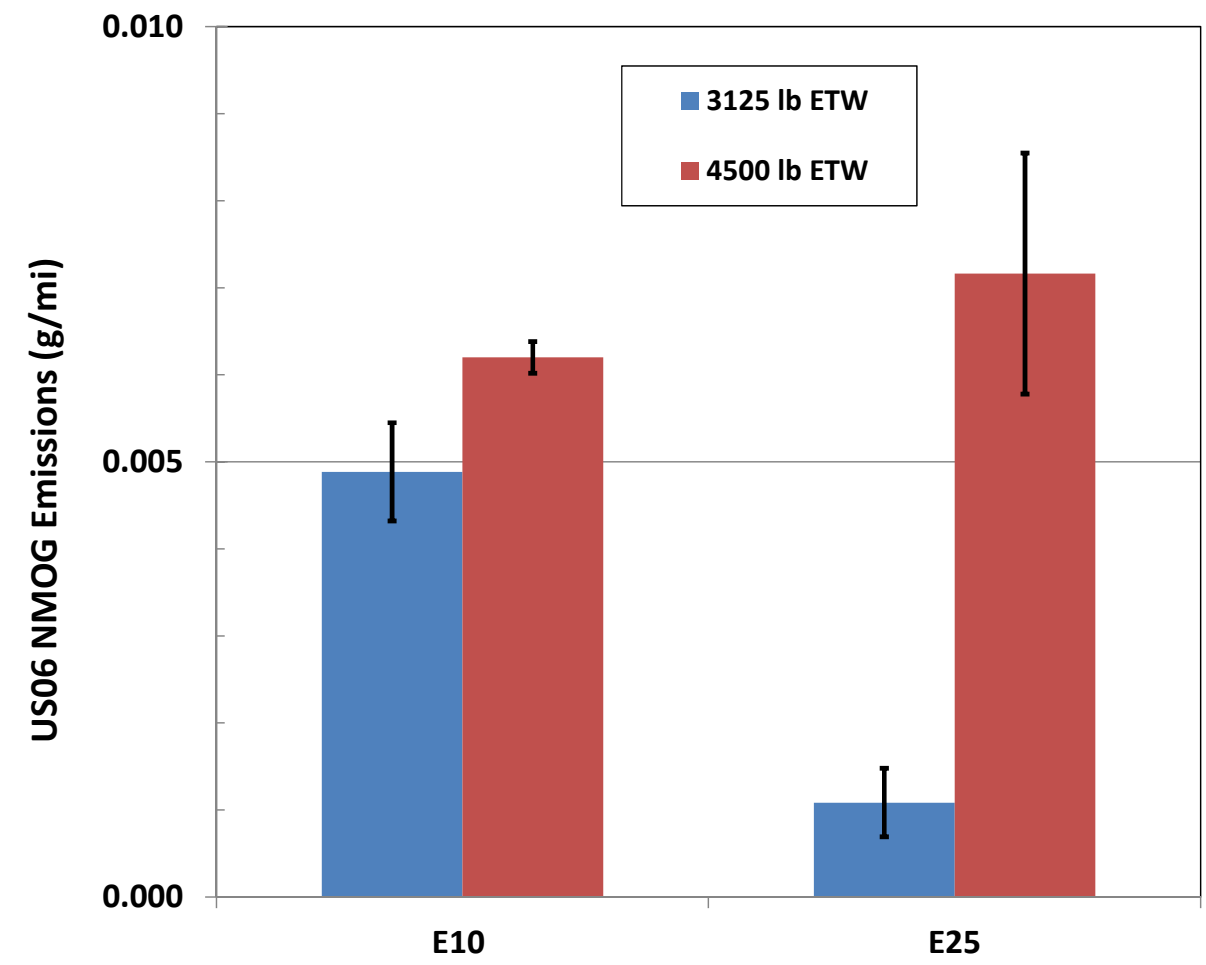

Figure 13. US06 NMOG emissions for 2015 MINI Cooper at two test weights with two fuels. Range bars indicate maximum and minimum for multiple tests. 


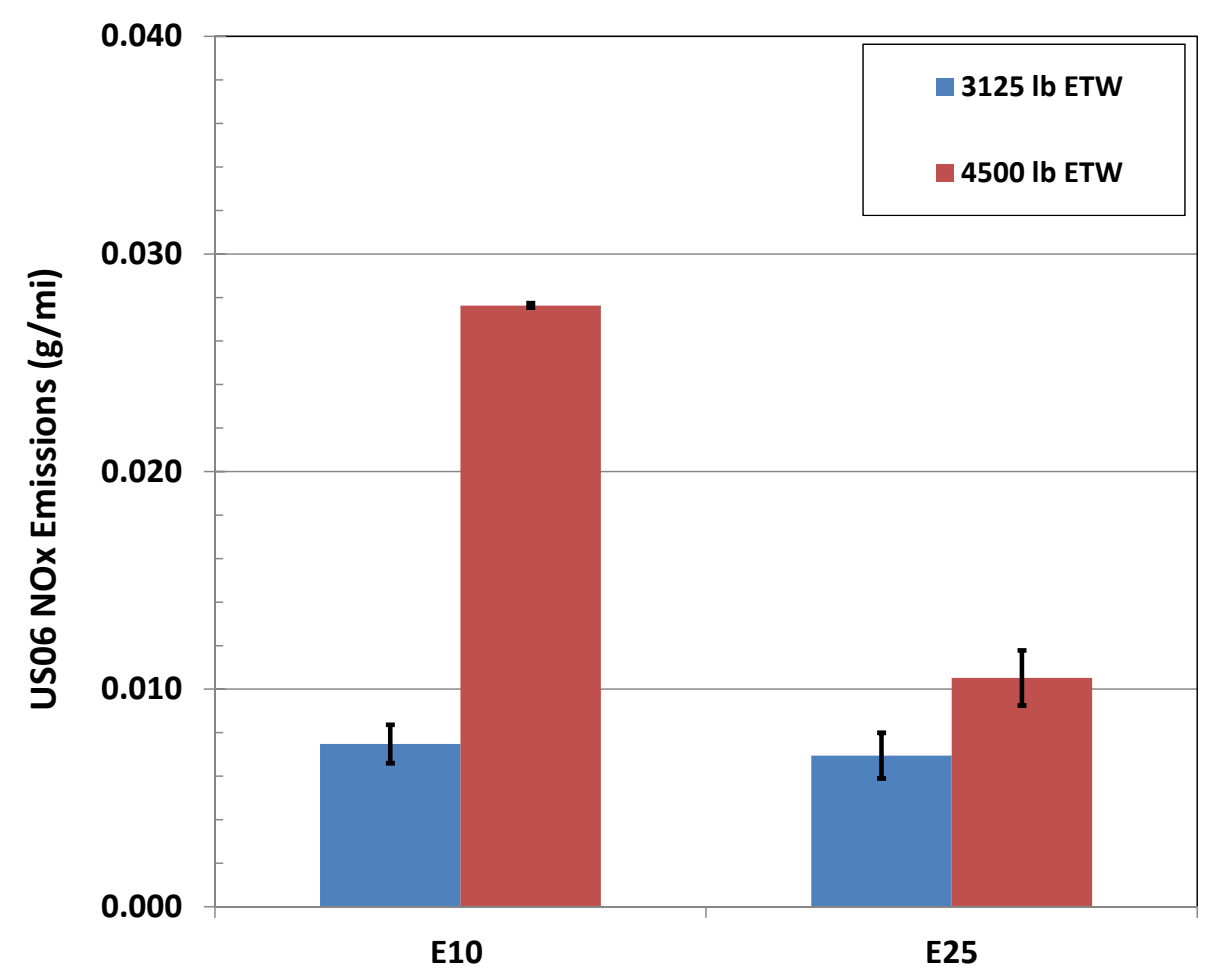

Figure 14. US06 NOx emissions for 2015 MINI Cooper at two test weights with two fuels. Range bars indicate maximum and minimum for multiple tests.

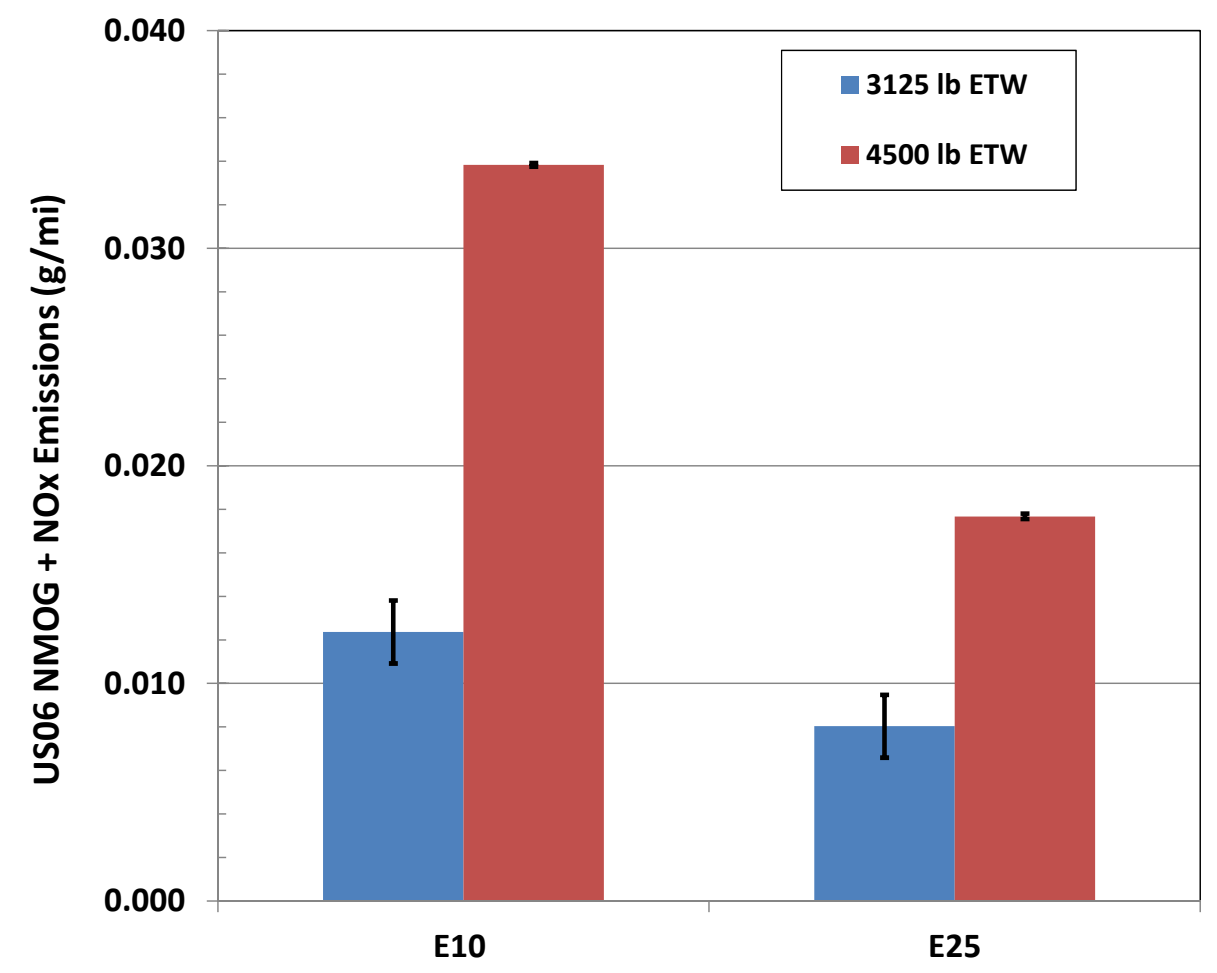

Figure 15. US06 NMOG+NOx emissions for MINI Cooper at two test weights with two fuels. Range bars indicate maximum and minimum for multiple tests. 


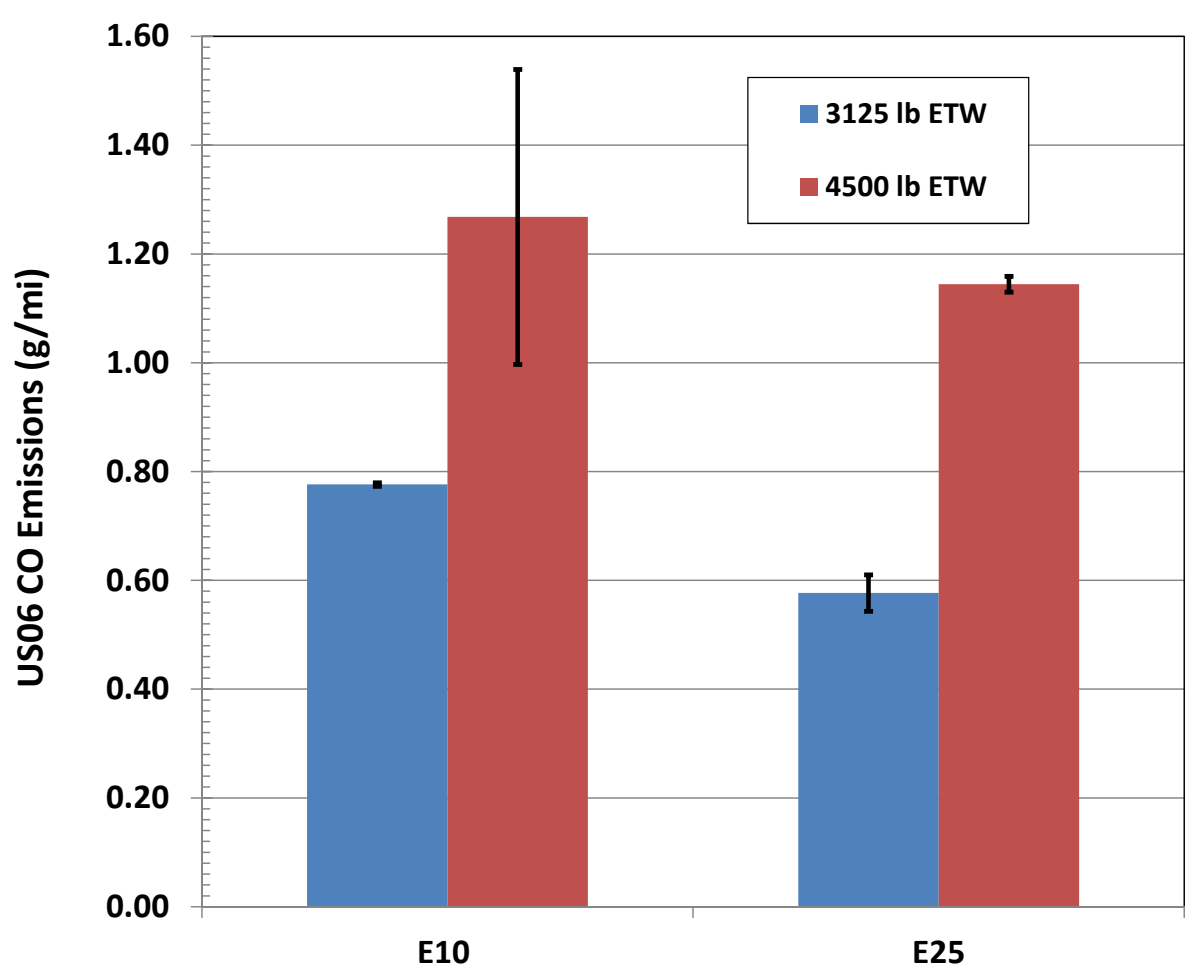

Figure 16. US06 CO emissions for MINI Cooper at two test weights with two fuels. Range bars indicate maximum and minimum for multiple tests.

\subsection{MINI COOPER VEHICLE ACCELERATION}

Wide open throttle acceleration tests were conducted on the vehicle dynamometer using the MINI Cooper ETW and dynamometer coefficients, and with the Dodge Charger ETW and coefficients. Plotted results are for minimum acceleration time from multiple test runs. Due to the potential variability associated with standing start launches and wheel spin, a "rolling start" acceleration was performed. All gear changes were done as quickly as possible but with full clutch disengagement and lifting of the throttle.

Dynamometer speed data were analyzed for time to accelerate from 15 to $80 \mathrm{mph}$. For the Charger test weight case with E25 an additional set of runs was conducted with an aftermarket "tuning chip" connected. The F56 Power Module from NM Engineering ${ }^{\dagger \dagger}$ connects to the factory harness to increase boost pressure and generate more horsepower. The pre-owned test vehicle was rented from a local dealer and the Power Module had been installed by a previous owner. The Power Module unit was disconnected for all testing described in this report except for one set of WOT tests as described below.

Results for 5 repeat WOT tests are shown in Table 8 and the minimum 15-80 mph elapsed time results are shown in Figure 17. The MINI accelerates from 15 to $80 \mathrm{mph}$ in about nine seconds with E10. Switching to E25 decreases the acceleration time by 0.4 seconds as shown in Figure 17 and Table 8 . If the median values are considered, the elapsed time differential remains at 0.4 seconds (from 9.2 to $8.8 \mathrm{~s}$ ).

\footnotetext{
${ }^{\dagger}$ NM Engineering, 3300 Corte Malpaso, Camarillo, CA 93012, http://www.nm-eng.com/338/0/0/3128/nm648846-nm-engpower-module.html
} 
Table 8. MINI Cooper S 15-80 mph acceleration times at two test weights with two fuels.

\begin{tabular}{clcccc} 
& \multicolumn{2}{c}{ MINI (3125 lb) } & \multicolumn{2}{c}{ Dodge Charger Emulation (4500 lb) } \\
\cline { 2 - 6 } Run & $\mathbf{E 1 0}$ & $\mathbf{E 2 5}$ & $\mathbf{E 1 0}$ & $\mathbf{E 2 5}$ & $\begin{array}{c}\text { E25 with Power } \\
\text { Module }\end{array}$ \\
\hline $\mathbf{1}$ & 9.41 & 8.61 & 13.59 & 12.61 & 10.60 \\
\hline $\mathbf{2}$ & 9.02 & 8.80 & 13.42 & 12.58 & 11.20 \\
\hline $\mathbf{3}$ & 9.01 & $10.60^{*}$ & 13.19 & 12.81 & 11.20 \\
\hline $\mathbf{4}$ & 9.22 & 8.81 & $14.78^{*}$ & 12.58 & $11.62^{*}$ \\
\hline $\mathbf{5}$ & $9.96^{*}$ & 8.82 & 13.02 & $13.42^{*}$ & 10.81 \\
\hline Minimum & 9.01 & 8.61 & 13.02 & 12.58 & 10.60 \\
\hline Median & 9.22 & 8.81 & 13.42 & 12.61 & 11.20 \\
\hline & *outliers due to missed shift (excluded from median calculations) \\
\hline
\end{tabular}

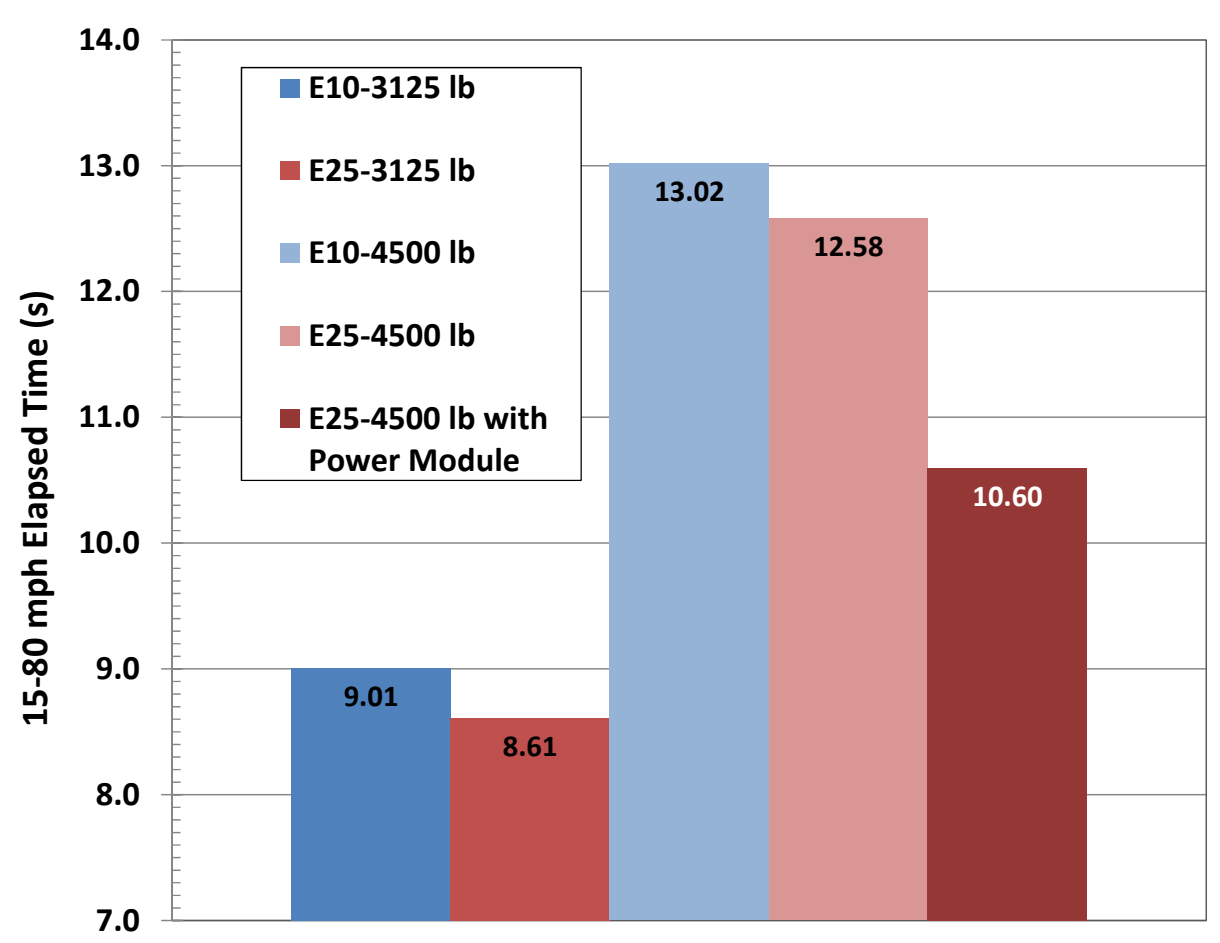

Figure 17. Minimum wide-open-throttle acceleration times for MINI Cooper with E10 and E25 at two test weights with two fuels.

With the dynamometer set to the 4500-lb. Charger test weight and road load, the car is considerably slower with both fuels, as expected, but for the best run in each case the high-octane E25 still returns a 0.4 second advantage. Considering the median value in this case increases the difference to 0.8 seconds (13.4 to $12.6 \mathrm{~s})$.

With the E25 fuel, the Power Module connected, and the $4500 \mathrm{lb}$. Charger dynamometer settings, the car improves the 15-80 mph time by a more significant margin of 2.4 seconds compared to the Charger case with the E10 fuel. Considering the median values for this comparison the advantage is 2.2 seconds (13.4 to $11.2 \mathrm{~s})$. These results demonstrate the potential for maintaining acceleration performance with extreme downsizing when manufacturers design turbocharged engines for high-octane fuels. 


\subsection{FORD F150 FUEL ECONOMY/EFFICIENCY}

As described in an earlier section, the 2016 Ford F150 test plan involved running at least five replicates of each test to enable statistical analysis.

Average fuel economy results for the multiple tests are shown in Table 9 along with maximum, minimum and the 95\% confidence limit. Results are also shown in Figure 18. In the OEM condition, there is no statistical difference in the energy-equivalent fuel economy on the FTP or HFET. On the knock-limited US06 test, the use of high-octane E25 provides a statistically-significant improvement of $2.2 \%$ over the regular Tier 3 E10.

With the high-compression pistons installed a statistically-significant 5\% fuel economy benefit is realized on the FTP and HFET and for the US06 cycle the benefit exceeds $6 \%$.

Table 9. Average fuel economy in MPGge for 2016 Ford F150 experiments with two fuels.

\begin{tabular}{|c|c|c|c|c|}
\hline $\begin{array}{c}\text { Fuel } \\
\text { (Compression } \\
\text { Ratio) }\end{array}$ & Test Result & $\begin{array}{c}\text { FTP } \\
\text { MPGge }\end{array}$ & $\begin{array}{c}\text { HFET } \\
\text { MPGge }\end{array}$ & $\begin{array}{c}\text { US06 } \\
\text { MPGge }\end{array}$ \\
\hline \multirow{4}{*}{$\begin{array}{c}\text { Tier } 3 \text { E10 } \\
(10: 1)\end{array}$} & Average & 19.5 & 28.7 & 17.6 \\
\hline & Maximum & 19.9 & 28.9 & 17.8 \\
\hline & Minimum & 19.3 & 28.5 & 17.5 \\
\hline & U95 & 0.29 & 0.18 & 0.11 \\
\hline \multirow{4}{*}{$\begin{array}{c}\text { Tier } 3 \text { E25 } \\
(10: 1)\end{array}$} & Average & 19.4 & 28.8 & 18.0 \\
\hline & Maximum & 19.6 & 28.9 & 18.1 \\
\hline & Minimum & 19.2 & 28.5 & 17.7 \\
\hline & U95 & 0.18 & 0.18 & 0.19 \\
\hline \multirow{4}{*}{$\begin{array}{c}\text { Tier } 3 \text { E25 } \\
(12.2: 1)\end{array}$} & Average & 20.5 & 30.1 & 18.7 \\
\hline & Maximum & 20.6 & 30.3 & 19.0 \\
\hline & Minimum & 20.4 & 29.8 & 18.4 \\
\hline & U95 & 0.09 & 0.25 & 0.29 \\
\hline
\end{tabular}

FTP=Federal Test Procedure; HFET=Highway Fuel Economy Test; US06=high-load, high-speed test; MPGge=miles per gallon gasoline equivalent; U95=Student's $t$ for $95 \%$ confidence limit 


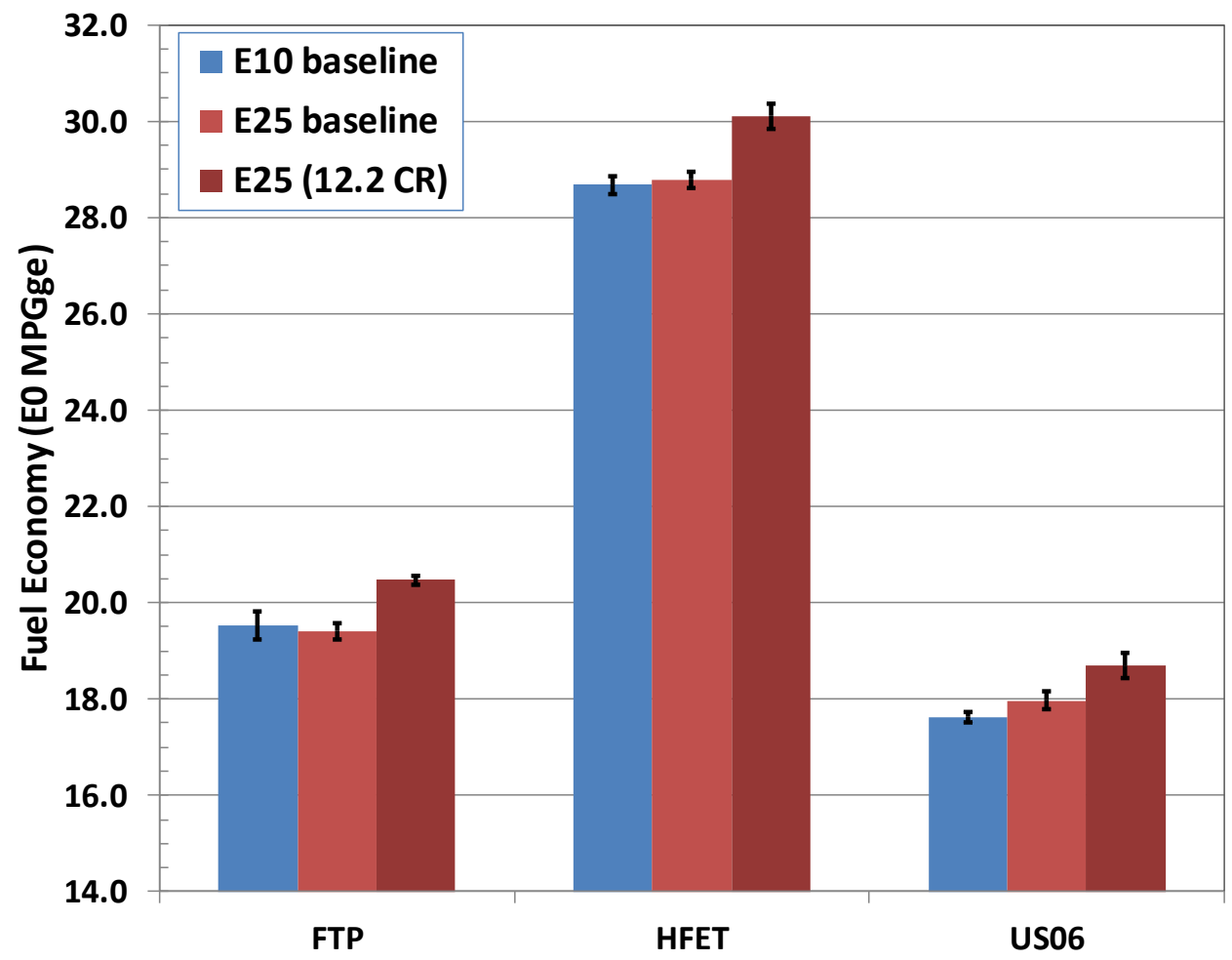

Figure 18. Ford F150 Fuel Economy in MPGge. Range bars indicate maximum and minimum for multiple tests. Baseline test results conducted at the factory compression ratio, 12.2 CR denote tests conducted after installation of high-compression pistons.

\subsection{FORD F150 BASELINE EMISSIONS}

A problem with the Flame Ionization Detector (FID) was discovered after completion of the F150 baseline experiments, thus the NMOG and NMOG + NOx emissions cannot be reported. NOx emissions with both fuels were variable and quite low, averaging $10.3 \mathrm{mg} / \mathrm{mi}$ with E10 and $12.9 \mathrm{mg} / \mathrm{mi}$ with E25 as shown in Table 10. In a two-sample t-test assuming unequal variances, the difference in NOx emissions with E10 and E25 are not significant at the 95\% confidence level.

Carbon monoxide emissions on the FTP were extremely low and are not tabulated, averaging $685 \mathrm{mg} / \mathrm{mi}$ with E10 and $437 \mathrm{mg} / \mathrm{mi}$ with E25. These differences in CO emissions are statistically significant at the $95 \%$ confidence level. The applicable Tier 2 Bin 4 CO limit for this vehicle is $2100 \mathrm{mg} / \mathrm{mi}$.

Three particulate matter (PM) measurements were collected with each fuel during the baseline experiments; each filter sampled two consecutive cold LA4 cycles as described in Section 2.2. The hot portion of the test was not sampled as particulate emissions are generally so low for this portion that many tests must be run to collect enough PM for a valid mass measurement. Six cold LA4 tests were run such that each PM filter collected mass from two consecutive cold LA4 tests. Particulate results are shown in Figure 19. The use of E25 results in a statistically-significant PM reduction of more than 35\%. 
Table 10. FTP NOx emissions for 2016 Ford F150 experiments with two fuels in the factory condition.

\begin{tabular}{|c|c|c|c|c|c|}
\hline Run & E10 (10:1) & $\begin{array}{c}\text { Average } \\
\mathrm{mg} / \mathrm{mi}\end{array}$ & $\begin{array}{c}\text { Maximum } \\
\mathrm{mg} / \mathrm{mi}\end{array}$ & $\begin{array}{c}\text { Minimum } \\
\text { mg/mi }\end{array}$ & U95 \\
\hline 1 & 11.2 & \multirow{5}{*}{10.3} & \multirow{5}{*}{12.1} & \multirow{5}{*}{5.6} & \multirow{5}{*}{3.4} \\
\hline 2 & 10.3 & & & & \\
\hline 3 & 5.6 & & & & \\
\hline 4 & 12.1 & & & & \\
\hline 5 & 12.1 & & & & \\
\hline Run & E25 (10:1) & & & & \\
\hline 1 & 12.9 & \multirow{5}{*}{12.7} & \multirow{5}{*}{14.0} & \multirow{5}{*}{10.9} & \multirow{5}{*}{1.5} \\
\hline 2 & 13.6 & & & & \\
\hline 3 & 14.0 & & & & \\
\hline 4 & 12.2 & & & & \\
\hline 5 & 10.9 & & & & \\
\hline
\end{tabular}

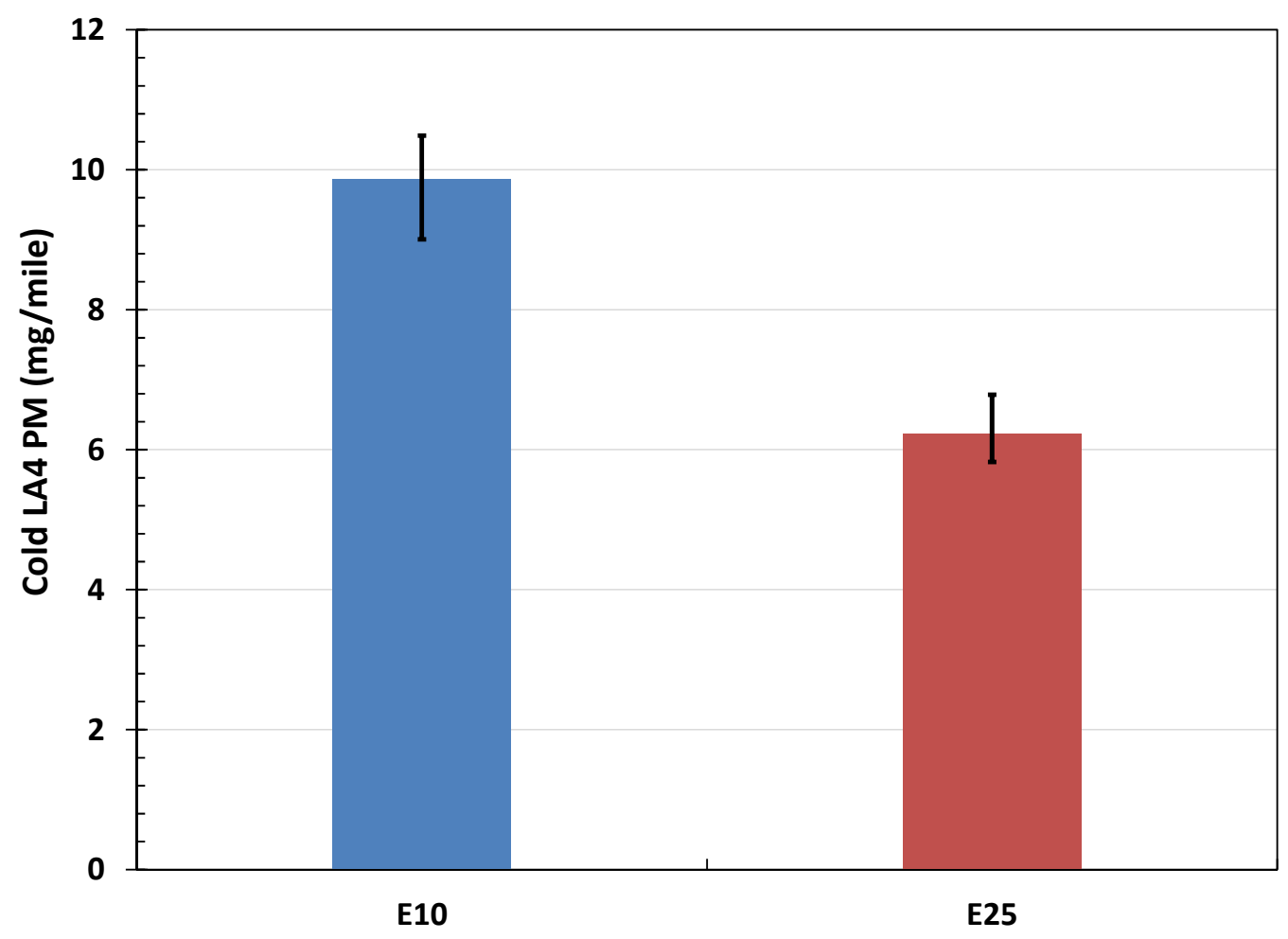

Figure 19. Cold LA4 particulate emissions for Ford F150 with two fuels. Range bars show maximum and minimum of 3 tests. 


\subsection{FORD F150 ACCELERATION}

Five WOT tests were run on the F150 in the OEM condition with each fuel. Similar to the MINI Cooper, the F150 accelerates about 0.4 seconds faster with the high-octane E25 fuel in the OEM condition, as shown in Table 11. Acceleration results with E25 after the compression ratio change were more variable with a modest improvement in minimum acceleration time. It is worthy of note that there were no changes to the engine calibration.

Table 11. F150 15-80 mph Acceleration Time with two fuels

\begin{tabular}{cccc}
\hline Run & E10 & E25 & E25 \\
& $\mathbf{( 1 0 : 1 )}$ & $\mathbf{( 1 0 : 1 )}$ & $\mathbf{( 1 2 . 2 : 1 )}$ \\
\hline $\mathbf{1}$ & 9.1 & 8.6 & 9.2 \\
\hline $\mathbf{2}$ & 9.7 & 9.4 & 8.3 \\
\hline $\mathbf{3}$ & 9.1 & 8.7 & 8.3 \\
\hline $\mathbf{4}$ & 9.0 & 8.7 & 8.5 \\
\hline $\mathbf{5}$ & 9.2 & 8.6 & 8.4 \\
\hline $\mathbf{6}$ & - & - & 8.5 \\
\hline Minimum & 9.0 & 8.6 & 8.3 \\
\hline Median & 9.1 & 8.7 & 8.4 \\
\hline
\end{tabular}

\section{SUMMARY}

A 2015 MINI Cooper S with 2.0-liter turbocharged, direct-injection engine and 6-speed manual transmission and a 2016 Ford F150 with 3.5-liter turbocharged, direct-injection engine and 6-speed automatic transmission were evaluated to demonstrate the effects of high-octane ethanol blends on these modern vehicles. The base fuel was a 92.2 RON Tier 3 E10; this fuel was splash-blended with ASTM D4806 fuel ethanol to produce a "Tier 3 E25" fuel with 98.7 RON. Net heating value of the E10 and E25 were taken as the average of two independent analyses.

Fuel economy for both vehicles on the FTP, HFET, and US06 is reported on an energy-equivalent basis in MPGge (miles per gallon gasoline equivalent). The MINI Cooper was tested at two equivalent test weights (ETW), $3125 \mathrm{lb}$. as in certification, and at $4500 \mathrm{lb}$. to emulate a large family sedan (Dodge Charger) and thus simulate downsizing. Downspeeding was achieved with the MINI Cooper by shortshifting at $80 \%$ of the normal EPA shift schedule. All MINI Cooper experiments were run in duplicate while the F150 was subjected to five or six consecutive tests for each experiment. 
Gaseous emissions were collected for both vehicles, and particulate emissions were collected for the cold LA4 portion of the FTP with the F150 during baseline testing. Unfortunately, a malfunctioning flame ionization detector precludes reporting the baseline F150 hydrocarbon emissions. Both vehicles were subjected to wide-open-throttle acceleration tests with both fuels.

Following the baseline tests on the F150, prototype 12.2:1 pistons were installed, replacing the factory 10:1 pistons. Comparing the 99 RON E25 results to the 92 RON E10 results, the following observations can be made:

- On an energy-equivalent basis, MPGge with E25 improved for several test conditions with both vehicles in the OEM condition. The largest benefits were noted for higher-load operation such as downspeeding and downsizing with the MINI Cooper, or on the high-load US06 test (both vehicles).

- Following the installation of 12.2:1 (high compression ratio) pistons in the F150, MPGge improved at all test conditions. With no changes to engine or transmission calibration the F150 MPGge was improved 5-6\% with E25 and high-compression pistons.

- Tailpipe FTP emissions for the MINI Cooper were within Tier 3 Bin 30 limits at $3125 \mathrm{lb}$. ETW, and potentially even at the heavier $4500 \mathrm{lb}$. ETW with both fuels.

o No significant fuel-related changes to NMOG, NOx, or NMOG+NOx were noted on the FTP or HFET. CO emissions were reduced with the use of E25 on the FTP and HFET.

o Not surprisingly, at the $4500 \mathrm{lb}$. ETW the MINI Cooper emissions were notably increased on the US06. The use of E25 at the higher test weight provided similar NMOG and $\mathrm{CO}$, and lower NOx emissions.

- Tailpipe NOx emissions for the F150 in the OEM condition were quite low and highly variable, showing no statistically significant fuel effect. Tailpipe $\mathrm{CO}$ was well below the Tier 2, Bin 4 limit with both fuels; E25 provided a statistically significant reduction in CO. A statistically significant reduction of particulate emissions was measured on the cold LA4 test with E25.

o No attempts were made to optimize the high-compression ratio combustion chamber or refine the engine calibration for the F150 engine rebuild. At the high compression ratio condition, NOx emissions were similar, but PM and NMOG were increased, suggesting that combustion chamber geometry, turbulence, and engine control could be refined for the high-compression ratio case.

- Both vehicles accelerate about 0.4 seconds $(15-80 \mathrm{mph})$ faster with high-octane E25 in the OEM condition. Increasing compression ratio in the F150 further improved acceleration with the E25 fuel.

o The use of an aftermarket tuner chip on the MINI Cooper with E25 at the $4500 \mathrm{lb}$. ETW significantly improved acceleration time $(2.4 \mathrm{~s})$. 


\section{REFERENCES}

${ }^{1}$ ASTM D2699-16e1. Standard test Method for research octane number of spark-ignition engine fuel. West Conshohocken, PA: ASTM International, 2016. Retrieved from www.astm.org

${ }^{2}$ ASTM D2700-16a. Standard test method for motor octane number of spark-ignition engine fuel. West Conshohocken, PA: ASTM International, 2016. Retrieved from www.astm.org

${ }^{3}$ Sluder, C. Scott, David E. Smith, Martin Wissink, James E. Anderson, Thomas G. Leone, and Michael Shelby, "Effects of Octane Number, Sensitivity, Ethanol Content, and Engine Compression Ratio on GTDI Engine Efficiency, Fuel Economy, and $\mathrm{CO}_{2}$ Emissions," CRC Report No. AVFL-20, November 2017, available at https://crcao.org/reports/recentstudies2017/AVFL20/AVFL20_Final\%20Report 11032017.pdf

${ }^{4}$ Szybist, J.P., Splitter, D.A., "Understanding Chemistry-Specific Fuel Differences at a Constant RON in a Boosted SI Engine,” Fuel, 2018, 217, pp 370-381, DOI: 10.1016/j.fuel.2017.12.100.

${ }^{5}$ Leone, T., Olin, E., Anderson, J., Jung, H., and Shelby, M., "Effects of Fuel Octane Rating and Ethanol Content on Knock, Fuel Economy, and $\mathrm{CO}_{2}$ for a Turbocharged DI Engine," SAE Int. J. Fuels Lubr. 7(1):9-28, 2014, https://doi.org/10.4271/2014-01-1228.

${ }^{6}$ Splitter, D.A., and Szybist, J.P., "Experimental Investigation of Spark-Ignited Combustion with HighOctane Biofuels and EGR. 2. Fuel and EGR Effects on Knock-Limited Load and Speed," Energy \& Fuels, 28(2): 1432-1445, 2014, doi:10.1021/ef401575e

${ }^{7}$ Splitter, D. and Szybist, J., "Intermediate Alcohol-Gasoline Blends, Fuels for Enabling Increased Engine Efficiency and Powertrain Possibilities," SAE Int. J. Fuels Lubr. 7(1):2014, doi:10.4271/2014-01-1231

${ }^{8}$ Szybist, J., M Foster, W. Moore, K. Confer, A. Youngquist, and R. Wagner, "Investigation of Knock Limited Compression Ratio of Ethanol Gasoline Blends," SAE Technical Paper 2010-01-0619, 2010, doi:10.4271/2010-01-0619.

${ }^{9}$ Szybist, J. and West, B., "The Impact of Low Octane Hydrocarbon Blending Streams on the Knock Limit of "E85"," SAE Int. J. Fuels Lubr. 6(1):44-54, 2013, https://doi.org/10.4271/2013-01-0888.

${ }^{10}$ Thomas G. Leone, James E. Anderson, Richard S. Davis, Asim Iqbal, Ronald A. Reese, II, Michael H. Shelby, and William M. Studzinski, "The Effect of Compression Ratio, Fuel Octane Rating, and Ethanol Content on Spark-Ignition Engine Efficiency," Environmental Science \& Technology 201549 (18), 10778-10789, DOI: 10.1021/acs.est.5b01420

${ }^{11}$ Theiss, Tim, Teresa Alleman, Aaron Brooker, Amgad Elgowainy, Gina Fioroni, et al, "Summary of High-Octane, Mid-Level Ethanol Blends Study," Oak Ridge National Laboratory, ORNL/TM-2016/42, July 2016, available at https://info.ornl.gov/sites/publications/files/pub61169.pdf

${ }^{12}$ David S. Hirshfeld, Jeffrey A. Kolb., James E. Anderson, William Studzinski, and James Frusti, "Refining Economics of U.S. Gasoline: Octane Ratings and Ethanol Content," Environmental Science \& Technology 201448 (19), 11064-1107, DOI: 10.1021/es5021668

${ }^{13}$ Thomas, John F., B. H. West, and S. P. Huff, "Effects of High-Octane Ethanol Blends on Four Legacy Flex-Fuel Vehicles, and a Turbocharged GDI Vehicle," ORNL/TM-2015/116, March 2015, available at https://info.ornl.gov/sites/publications/files/Pub54888.pdf

${ }^{14}$ Sluder, C. Scott, David E. Smith, and Brian H. West, “An Engine and Modeling Study on Potential Fuel Efficiency Benefits of a High-Octane E25 Gasoline Blend," Oak Ridge National Laboratory, ORNL/TM-2017/357, August 2017, available at https://info.ornl.gov/sites/publications/Files/Pub100128.pdf 
${ }^{15}$ USDA, 2015. "USDA to Invest up to $\$ 100$ Million to Boost Infrastructure for Renewable Fuel Use, Seeking to Double Number of Higher Blend Renewable Fuel Pumps," Press Release No. 0156.15, May 29, 2015; available online at https://www.usda.gov/media/press-releases/2015/05/29/usda-invest-100million-boost-infrastructure-renewable-fuel-use

${ }^{16}$ Wayne Fueling Systems, 2016. "Wayne Standardizes Offering for All North American Retail Fuel Dispensers to E25/B20," Press Release, August 2016, available online at https://wayne.com/en/pressreleases/2016-08-30-wayne-standardizes-offering-for-all-north-american-retail-fuel-dispensers-to-e25/

${ }^{17}$ Knoll, Keith, Brian West, Shean Huff, John Thomas, John Orban, Cynthia Cooper, "Effects of MidLevel Ethanol Blends on Conventional Vehicle Emissions," SAE Technical Paper 2009-01-2723, 2009, doi:10.4271/2009-01-2723

${ }^{18}$ West, Brian H., Scott Sluder, Keith Knoll, John Orban, Jingyu Feng, Intermediate Ethanol Blends Catalyst Durability Program, ORNL/TM-2011/234, February 2012, available at http://info.ornl.gov/sites/publications/Files/Pub31271.pdf

${ }^{19}$ BMW AG, 2015 MINI Cooper Owner's Manual, Munich, Germany

20 "Download Fuel Economy Data," accessed March 13, 2018, at https://www.fueleconomy.gov/feg/download.shtml

${ }^{21}$ Sluder, Scott, Kristi Moriarty, Forrest Jehlik, and Brian H. West, "Misfueling Mitigation," (Technical Report) Oak Ridge National Laboratory 2017. DOE/GO-102017-4896. Available at https://www.nrel.gov/docs/fy17osti/66918.pdf

2240 CFR Pt. 1066

${ }^{23}$ Ford Motor Company, 2016 F150 Owner's Manual

${ }^{24}$ Zhang, S. and McMahon, W., "Particulate Emissions for LEV II Light-Duty Gasoline Direct Injection Vehicles," SAE Int. J. Fuels Lubr. 5(2):2012, doi:10.4271/2012-01-0442

${ }^{25}$ Storey, John, Melanie DeBusk, Shean Huff, et al., "Characterization of GDI PM during start-stop operation with alcohol fuel blends," presented at Health Effects Institute Workshop, Chicago IL, December 2016, available at https://www.healtheffects.org/sites/default/files/StoreyCharacterization of GDI PM.pdf

${ }^{26}$ Aikawa, K., Sakurai, T., and Jetter, J., "Development of a Predictive Model for Gasoline Vehicle Particulate Matter Emissions," SAE Int. J. Fuels Lubr. 3(2):610-622, 2010, https://doi.org/10.4271/201001-2115.

${ }^{27} 40$ CFR Pt. 600.

${ }^{28}$ Hochhauser, Albert M., Jack D. Benson, Vaughn R. Burns, et al., "Fuel Composition Effects on Automotive Fuel Economy-Auto/Oil Air Quality Improvement Research Program,” SAE paper 930138, SAE International, Warrendale, Pennsylvania, March 1993.

${ }^{29}$ Sluder, C., West, B., Butler, A., Mitcham, A., and Ruona, W., "Determination of the R Factor for Fuel Economy Calculations Using Ethanol-Blended Fuels over Two Test Cycles," SAE Int. J. Fuels Lubr. 7(2):2014, doi:10.4271/2014-01-1572

${ }^{30}$ Sluder, C. Scott, and Brian H. West, NMOG Emissions Characterizations and Estimation for Vehicles Using Ethanol-Blended Fuels, ORNL/TM-2011/461, Oak Ridge National Laboratory, October 15, 2011, available at http://info.ornl.gov/sites/publications/Files/Pub33272.pdf.

${ }^{31}$ Sluder, C. and West, B., "NMOG Emissions Characterizations and Estimation for Vehicles Using Ethanol-Blended Fuels," SAE Int. J. Fuels Lubr. 5(2):721-732, 2012, doi:10.4271/2012-01-0883. 
${ }^{32}$ Federal Register, Vol. 79(81), Monday, April 28, 2014, Rules and Regulations, "Control of Air Pollution From Motor Vehicles: Tier 3 Motor Vehicle Emission and Fuel Standards; Final Rule." 